\title{
Progress in Developing Scale-Able Approaches to Field-Scale Water Accounting Based on Remote Sensing
}

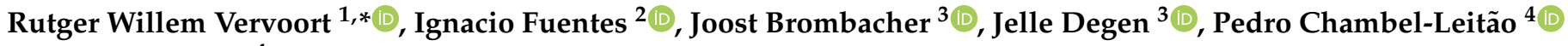 \\ and Flávio Santos ${ }^{4}$
}

check for updates

Citation: Vervoort, R.W.; Fuentes, I.; Brombacher, J.; Degen, J.;

Chambel-Leitão, P.; Santos, F.

Progress in Developing Scale-Able

Approaches to Field-Scale Water

Accounting Based on Remote

Sensing. Sustainability 2022, 14, 2732.

https://doi.org/10.3390/su14052732

Academic Editor: Daowei Sun

Received: 31 December 2021

Accepted: 21 February 2022

Published: 25 February 2022

Publisher's Note: MDPI stays neutral with regard to jurisdictional claims in published maps and institutional affiliations.

Copyright: (C) 2022 by the authors. Licensee MDPI, Basel, Switzerland. This article is an open access article distributed under the terms and conditions of the Creative Commons Attribution (CC BY) license (https:// creativecommons.org/licenses/by/ $4.0 /)$.
1 Data Analytics for Resources and the Environment Industry Transformation Training Centre and School of Life and Environmental Sciences, The University of Sydney, Sydney, NSW 2006, Australia

2 WaterTechnology Pty, Ltd., Notting Hill, VIC 3168, Australia; ignacio.fuentes.sanroman@gmail.com

3 eLEAF B.V., 6703CT Wageningen, The Netherlands; joost.brombacher@eleaf.com (J.B.); jelle.degen@eleaf.com (J.D.)

4 Hidromod LDA, Porto Salvo, 2740-278 Lisboa, Portugal; pedrochambelleitao@hidromod.com (P.C.-L.); flavio.santos@hidromod.com (F.S.)

* Correspondence: willem.vervoort@sydney.edu.au

\begin{abstract}
To increase water productivity and assess water footprints in irrigated systems, there is a need to develop cheap and readily available estimates of components of water balance at fine spatial scales. Recent developments in satellite remote sensing platforms and modelling capacities have opened opportunities to address this need, such as those being developed in the WaterSENSE project. This paper showed how evapotranspiration, soil moisture, and farm-dam water volumes can be quantified based on the Copernicus data from the Sentinel satellite constellation. This highlights distinct differences between energy balance and crop factor approaches and estimates that can be derived from the point scale to the landscape scale. Differences in the results are related to assumptions in deriving evapotranspiration from remote sensing data. Advances in different parts of the water cycle and opportunities for crop detection and yield forecasting mean that crop water productivity can be quantified at field to landscape scales, but uncertainties are highly dependent on input data availability and reference validation data.
\end{abstract}

Keywords: water use efficiency; Copernicus satellite data; irrigated agriculture

\section{Introduction}

Water is crucial for all natural systems, including human life [1]. For example, feeding the world's population is dependent on having sufficient water available [2], but human use of water is also causing significant stress on natural ecosystems [3]. Globally, through the sustainable development goals (https: / / sdgs.un.org/) (accessed on 20 February 2022) and, for example, through the European Green Deal (https:/ / ec.europa.eu/info/strategy / priorities-2019-2024/european-green-deal_en) (accessed on 20 February 2022), there is an increased focus on improving water use efficiency and the management of water losses. Closing the "yield gap" by improving crop water productivity has therefore been an important area of research [4,5] as this can potentially increase food production while minimising environmental stresses [6].

A key tool to investigate the sustainability of crop production as a function of water use is through water footprints [3,7]. Water footprint research now covers almost 20 years since the original article by Hoekstra and Hung [8]. However, Quintero et al. [7] identified the key limitations to apply water footprint analysis for the two main directions in this research area. These limitations include a lack of accurate spatial ET estimates, lack of understanding of the fine scale spatial variation in inputs and outputs, and lack of understanding of on-farm storage of water. 
Furthermore, there are major data limitations in capturing the desired detail in the water cycle, across large areas such as in the Western US [9] and the Murray Darling Basin in Australia [10]. Observations on-the-ground from gauging are sparse, and data on actual withdrawals and crop water use are often limited $[9,11,12]$. The problem is further exacerbated by economic rationalisation in many hydrometric departments, resulting in a decline in the actual number of observation points [13].

As a result, many global water footprint and water productivity studies are on very large spatial and temporal scales $[3,14]$ as the spatial data often are not available at finer scales. Typical scales for water footprints are 5 arc-seconds per grid cell for the spatial extent and monthly scales in the time domain $[3,15]$. Alternatively, the data can be analysed at county level [16], which can still be large. Finally, water footprints or crop productivity analysed at a single point using crop modelling $[17,18]$ do not easily scale to the larger catchment or country scale.

In contrast, improving on-farm water management and maximising green water use for crop productivity requires tools and quantification at much smaller scales from the field (paddock) to the farm scale [19]. In addition, irrigation scheduling applications require temporal scales that are shorter than a month [20]. All of this will require data at a much finer spatial and temporal scale than has been demonstrated so far [19], which is also needed if the focus is on policy compliance for environmental flow assessments [10]. However, investment in monitoring is expensive [21] and as a result the majority of irrigation systems remain unmonitored. Therefore, we need smart and new ways to observe the water balance at fine scales to enable improvements in water productivity (e.g., [22]).

Luckily there are new approaches using finer-scale satellite data (e.g., Sentinel data as part of the EU Copernicus initiative) to observe the water cycle in much more detail $[20,23,24]$. However, as water information can only be inferred from satellite data rather than directly measured, there is a need for novel algorithms and direct testing against observed data. In addition, other data, such as data on soils, land cover, and digital elevation models (DEM) are generally needed to calculate and derive water cycle components [23-28]. Some of these might again be derived from remote sensing observations [23].

Over time, many algorithms have been developed to estimate water balance components (for example, see Calera et al. [20] for a list of ET algorithms based on remote sensing). However, many of the algorithms are limited in application to specific locations, specific crops, or specific landscape systems. For real applied water-cycle monitoring for water accounting purposes and crop productivity, the challenge remains to develop a library of algorithms that can be applied at any point on the globe at temporal and spatial scales that link to management.

Despite the huge potential of remote sensing to observe the water cycle, challenges related to observing the water cycle have been well-documented over the last decade, e.g., [29-33]. Until recently, the spatial and temporal scale of satellite observations has been an issue [33,34]. However, new satellite constellations, such as Sentinel (e.g., [23,35]), have relatively finer spatial and temporal scales. However, an additional effect from the increase in temporal frequency and finer spatial scales is an increase in data volumes and processing. Some of this is alleviated by the development of cloud-based systems for spatial data processing, such as Google Earth Engine [36], and in the future it can be expected that more of these solutions will be developed, making processing, analysing, and displaying detailed satellite data easier.

A further major issue, as highlighted by several of the recent reviews (e.g., [31,33]), is the continued dominance of localised regression or other data-based techniques to derive relationships between satellite data and environmental data. This results in mostly local relationships in space and time, and often related to a specific land cover or water cycle element that cannot be easily extended to more global relationships. Far fewer papers focus on developing models that make use of the physical properties of the land cover or water cycle process and the way this is observed using the satellite sensors. For example, using the energy balance method (e.g., [37]), spatial contrasts in the observed landscape can be 
used to analyse energy differences and therefore estimate actual evapotranspiration. Such methods are more generalised and more widely applicable.

Overall, remote sensing can be used quite effectively to observe fluxes and state variables from the water cycle [30]. Evapotranspiration, precipitation, soil moisture, surface water levels, streamflow, water quality, and groundwater storage can generally be observed through remote sensing [32]. These variables can be directly used in hydrological models, but are also of value for the agricultural sector, in particular for managing irrigation. Examples of products aimed towards irrigation in the agricultural sector are providing irrigated water use and water extent estimates [12], irrigation efficiency evaluations [38], water accounting [34] reservoir volume estimates [27], and footprint assessments [39]. From these papers, Feng et al. [39], based on a quantitative literature review, also indicated that there are limited water footprint analyses using remote sensing.

Many of the remote sensing-based water cycle observations can be (and have been) verified using in situ data. There has been extensive work on testing evapotranspiration (ET) satellite products against in situ data (i.e., [23,40]), as well as several large scale campaigns to verify soil moisture products [41,42], and large continental scale comparisons of the overall water balance $[43,44]$.

However, most of the verification studies rely on a limited set of publicly available global data or are based on relatively small local data sets which cannot be extrapolated easily to other areas. To generalise the prediction of water cycle using satellite data, there is a continued need to collect validation data, particularly if the prediction spatial scale is finer. While there are substantial datasets for large water bodies (for example https:/ / dashboard. waterdata.usgs.gov/app/nwd/ and http://www.bom.gov.au/waterdata/) (accessed on 20 February 2022), there are essentially no observed data from on-farm irrigation reservoirs. Similarly, while there are substantial datasets on modelled evapotranspiration, there are very few direct observations of vegetation sapflow that could link fine scales to satellite observations [45].

As a result, there are significant uncertainties in the observation of finer-scale watercycle processes, and these uncertainties would need to be quantified [21,27]. More specifically, the focus should be on the lack of accurate spatial ET estimates, lack of understanding of the fine scale spatial variation in inputs and outputs, and lack of understanding of on-farm storage of water [7].

In summary, three major remaining challenges remain if detailed water accounting and water productivity tools need to be developed that can be scaled from the field and farm to the continent level:

- The lack of detailed fine scale observations in space and time of water cycle components, particularly for soil moisture, farm dam volumes, and vegetation transpiration;

- The need for models linking satellite data and water cycle components that are transferable in space and time, most likely using physical relationships or through fast self-calibrating data-based models; and

- The need to quantify uncertainties in the satellite and water cycle relationships beyond reporting simple root mean square errors or bias.

However, there are continued efforts to develop new tools, one of which is the EU-funded WaterSENSE project (https:/ / www.watersense.eu/) (accessed on 20 February 2022).

The objectives of this paper are, therefore, to firstly show progress towards an operational water cycle observation system for water accounting and water footprints at the farm and field scale based on a case study in Australia and, secondly, to outline the challenges to extend this system to other places in the world and the projected uncertainties related to input data availability.

\section{Materials and Methods}

This paper concentrates on Australia because it offers a unique situation where water productivity is essential for maintaining agricultural export GDP, but there is extensive public scrutiny of the impact of irrigation on a sensitive environment $[10,28]$. In addition, 
Australia is fairly data rich [21], and therefore can be a good case study to investigate inherent uncertainties and further development needs.

In the case studies, we demonstrate several applications of remote sensing to deliver on-farm water accounting for crop productivity and water footprint analyses. These applications were developed as part of the EU funded WaterSENSE project.

\subsection{Case Studies}

Two paddocks located in the Namoi catchment were selected as case study areas (Figure 1). The Namoi catchment is a large catchment $\left(44,000 \mathrm{~km}^{2}\right)$ located in New South Wales, Australia. It is a region with intensive agriculture and large areas of cotton production. The selected study case areas are near the town of Narrabri in the middle of the catchment, and border the Namoi River, which functions as the main source for irrigation water. The study site $\mathbf{a}$ is located at approximate coordinates $149.9^{\circ}$ and $-30.4^{\circ}$ (WGS 1984) at a mean elevation of $226.9 \mathrm{~m}$ and covers an area of $1032.57 \mathrm{ha}$. The site has a subtropical climate with no dry season, a mean annual rainfall of $629 \mathrm{~mm}$, a mean temperature of $18.7^{\circ} \mathrm{C}$, with a mean minimum temperature of $11.4^{\circ} \mathrm{C}$ and a mean maximum temperature of $26^{\circ} \mathrm{C}$. Site $\mathbf{b}$ is located nearby at approximate coordinates $150^{\circ}$ and $-30.5^{\circ}$ at a mean elevation of $233.1 \mathrm{~m}$ and is $460.55 \mathrm{ha}$. The site has a similar climate, with a mean annual rainfall of $615 \mathrm{~mm}$ and a mean annual temperature of $18.6^{\circ} \mathrm{C}$, with a mean minimum of $11.3^{\circ} \mathrm{C}$ and a mean maximum of $25.9^{\circ} \mathrm{C}$ (http://www.bom.gov.au/climate/averages/maps.shtml) (accessed on 20 February 2022).

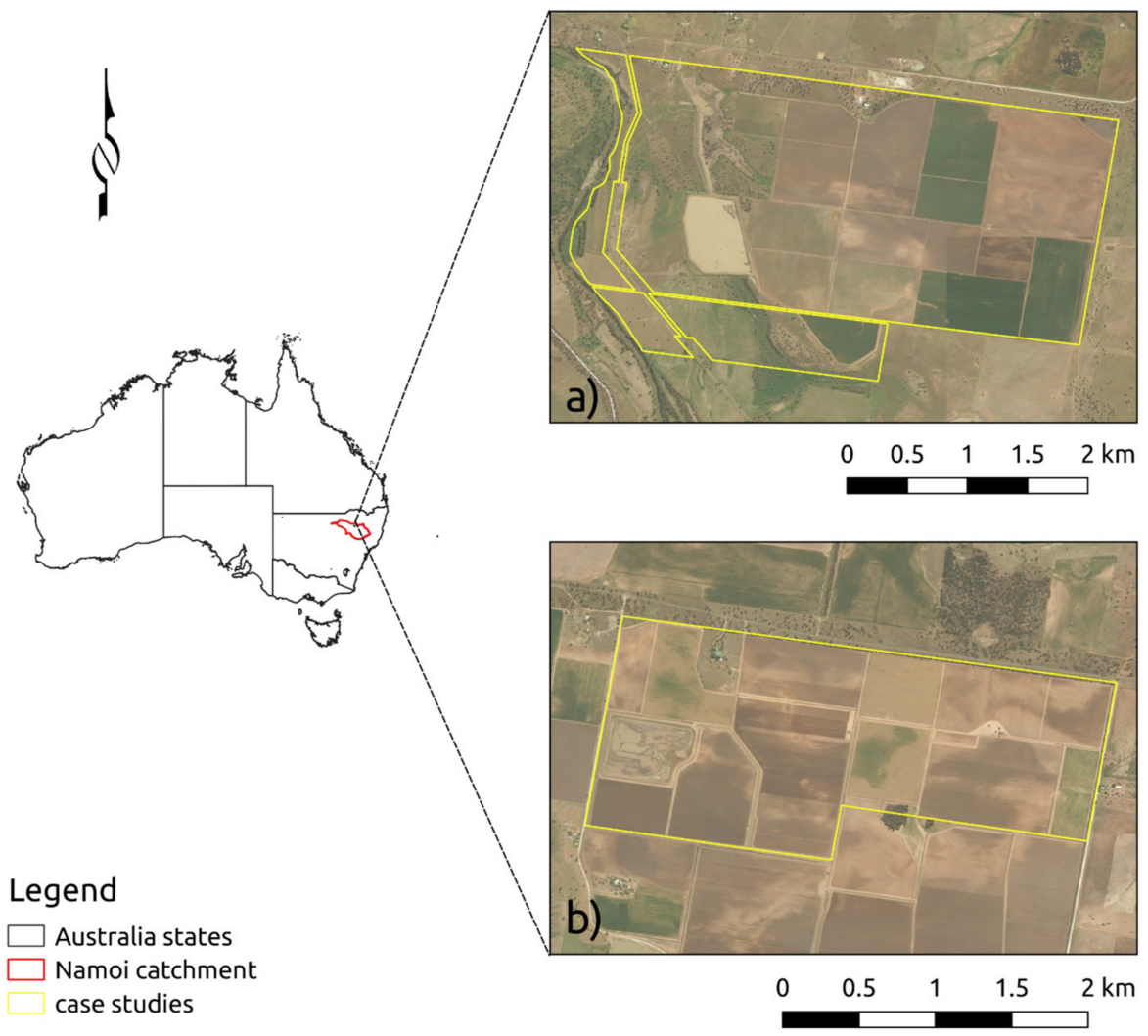

Figure 1. Case study sites in the Namoi catchment.

\subsection{Data Sources}

The sentinel $2 \mathrm{MSI}$, level 1C Top of Atmosphere (TOA) reflectance collection was used as an input to estimate different water budget components [46]. The collection was filtered based on the boundaries of the study sites and limited to the agricultural year 2017 (from 1 July 2017to 30 June 2018). It was merged with the cloud probability collection derived from Sentinel 2 images through the s2cloudless library [47]. From this collection, pixels that 
contained a cloud probability greater than $30 \%$ were masked out from the Sentinel 2 images. The Sentinel 2 collection was further filtered based on the properties of the images, filtering out images that contained more than $15 \%$ cloudy pixels.

Monthly rasters of the Global Precipitation Measurement (GPM) version 6 were downloaded for precipitation input [48]. These rasters are monthly aggregations of rainfall at 0.1-degree spatial resolution that are processed through a unified algorithm for precipitation combining different sources of passive microwave instruments. We used global data here to demonstrate the application of methods to any location on the globe. Monthly aggregates of temperature, wind speed, and surface pressure from the European Centre for Medium-Range Weather Forecasts (ECMWF) Reanalysis version 5 (ERA5) collection at 0.25 degree resolution [49] were combined with the monthly average forcing shortwave incoming radiation band from the Famine Early Warning System Network (FEWS NET) Land Data Assimilation System (FLDAS) collection at 0.1 degree resolution [50] to calculate reference evapotranspiration. Again, the analysis was based on globally available data to highlight the current "state of play" in this section.

Water-use information per field cluster was obtained from the New South Wales Department of Planning, Industry and Environment (DPIE). This information is monthly aggregated. Additionally, modeling of water volumes in reservoirs was based on the Sentinel 2 data and LiDAR data. The LiDAR data was extracted from the ELVIS-Elevation and Depth-Foundation Spatial Data webpage (https:/ / elevation.fsdf.org.au/ accessed on 20 February 2022). A series of $1 \mathrm{~m}$ resolution DEM tiles was downloaded and mosaicked, covering the study region surface.

Given the monthly scale of the NSW DPIE water-use data, all other data sources were aggregated to monthly data, including the reflectance information, which was averaged by month. Different spatial and temporal scales can be used for the estimates of the water cycle, but these will depend on the data sources used and the associated temporal resolution. For instance, while the forcing variable of the incoming radiation from the FLDAS data is aggregated by month, it can be replaced by the radiation contained in the Global Land Data Assimilation System (GLDAS) collection, which is based on 3-h estimates. The same applies to the ERA5 climate data, which can also be aggregated at a daily scale.

\subsection{Water Demand}

Water demand was assumed to be equal to the actual evapotranspiration lumped at the field scale. In this study, we compare the results of two remote sensing-based evapotranspiration algorithms, i.e., CMRSET [51] and ETLook [37], both using the Sentinel2 collection [51].

For the CMRSET algorithm, we assumed a similar wavelength range between Sentinel 2 and the Moderate Resolution Imaging Spectroradiometer (MODIS) sensors, as the CMRSET methodology was developed and validated based on MODIS surface reflectance data. Thus, the crop coefficient $(\mathrm{Kc})$ was calculated as:

$$
K_{c}=K_{c \max }\left(1-\exp \left(-a \times E V I_{r}^{\alpha}-b \times R M I^{\beta}\right)\right)
$$

where $K_{c} \max , a, \alpha, b, \beta$ are parameters empirically calibrated for Australia and are 0.68 , $14.12,2.482,-7.991$, and 0.89 . In this case, $E V I_{r}$ corresponds to the rescaled Enhanced Vegetation Index $(E V I)$, where EVI was calculated based on:

$$
E V I=G \times \frac{\rho_{\text {NIR }}-\rho_{\text {Red }}}{\rho_{\text {NIR }}+C 1 \times \rho_{\text {Red }}-C 2 \times \rho_{\text {Blue }}+L}
$$

In Equation (2), $\rho_{N I R}, \rho_{\text {Red }}$, and $\rho_{\text {Blue }}$ are the reflectances in the near-infrared, red, and blue wavelength spectrum, while $G$ and $L$ are the gain factor and a canopy background set to 2.5 and 1, respectively. $E V I_{r}$ was then calculated by clipping $E V I$ to a minimum of 0 and 
a maximum of 0.9 . The $R M I$ or Residual Moisture Index is a similar scaled index truncated at 0 and 1 , and was calculated by first calculating:

$$
R M I=G V M I-\left(K_{R M I} \times E V I+C_{R M I}\right)
$$

where $K_{R M I}$ and $C_{R M I}$ parameters have been calibrated in Australia, and correspond to 0.775 and -0.0757 , respectively. GVMI is the Global Vegetation Moisture Index, which can be calculated as:

$$
G V M I=\frac{\left(\rho_{N I R}+0.1\right)-\left(\rho_{S W I R 2}+0.02\right)}{\left(\rho_{N I R}+0.1\right)+\left(\rho_{S W I R 2}+0.02\right)}
$$

where $\rho_{S W I R 2}$ is the reflectance for the shortwave infrared wavelength of the spectrum.

The actual evapotranspiration (AET) was then calculated using the FAO56 methodology [52]:

$$
A E T=E T_{r} \times K_{c}
$$

And $E T_{r}$ is the reference evapotranspiration calculated using the FAO PenmanMonteith equation [52]:

$$
E T_{r}=\frac{0.408 \Delta\left(R_{n}-G\right)+\gamma \frac{C_{n}}{T+273} u_{2}\left(e_{s}-e_{a}\right)}{\Delta+\gamma\left(1+C_{d} u_{2}\right)}
$$

where $R_{n}$ is the net radiation, $\mathrm{G}$ is the soil heat flux, $\Delta$ the saturation vapor pressuretemperature slope, $u_{2}$ the mean wind speed measured at $2 \mathrm{~m}, T$ the mean daily temperature, $\gamma$ corresponds to the psychrometric constant, $e_{s}$ to the saturation vapor pressure, $e_{a}$ the actual pressure vapor, while $C_{d}$ and $C_{n}$ are constants for standard short crops, equivalent to 0.34 and 900 , respectively.

The second approach was to use the ETLook algorithm to calculate the AET. This algorithm is based on the energy budget equation [37]:

$$
R_{n}-G=\lambda E+H
$$

In this budget, $\lambda E$ is the latent heat flux and $\mathrm{H}$ is the sensitive heat flux. In the ETLook algorithm, evapotranspiration is split into the evaporation component:

$$
E=\frac{\Delta\left(R_{n, \text { soil }}-G\right)+\rho c_{p}\left(\frac{\Delta_{e}}{r_{a, \text { soil }}}\right)}{\Delta+\gamma\left(1+\frac{r_{\text {soil }}}{r_{a, \text { soil }}}\right)}
$$

and the transpiration component:

$$
T=\frac{\Delta\left(R_{n, \text { canopy }}-G\right)+\rho c_{p}\left(\frac{\Delta_{e}}{r_{a, \text { canopy }}}\right)}{\Delta+\gamma\left(1+\frac{r_{\text {canopy }}}{r_{a, \text { canopy }}}\right)}
$$

both following typical Penman Monteith descriptions. Here, $\rho$ is the air density and $C_{p}$ the specific heat or dry air, with radiation inputs for soil $\left(R_{n, \text { soil }}\right)$ and canopy $\left(R_{n, \text { canopy }}\right)$, and resistances for soil $\left(r_{\text {soil }}\right)$ and canopy $\left(r_{\text {canopy }}\right)$, and associated aerodynamic resistances for soil $\left(r_{a, \text { soil }}\right)$ and canopy $\left(r_{a, \text { canopy }}\right)$. The meteorological data necessary to derive these parameters were acquired from the Goddard Earth Observing System (GEOS) [53]. In addition, local data from the Bureau of Meteorology were used (www.bom.gov.au accessed on 20 February 2022). The transmissivity was derived from the geostationary Himawari satellite [54]).

\subsection{Water Supply}

Two sources of water supply were assumed. The first was the monthly rainfall obtained from GPM rasters. Since GPM rainfall corresponds to average hourly values $\left(\mathrm{mm} \mathrm{h}^{-1}\right)$, 
these rasters were rescaled to the monthly aggregates by multiplying the individual rasters by $24 \mathrm{~h}$ and the number of days in the month.

The second input was based on the monthly water use data supplied by NSW DPIE $\left(W_{u s e}\right)$. In some cases, more than a single record existed for each month, in which case the clusters were aggregated by month.

\subsection{A Measure of Efficiency in Water Use}

A water budget was implemented to understand the efficiency of the on-field water usage. The water deficit can be calculated as:

$$
W_{\text {def }}=A E T-P p
$$

where $P p$ corresponds to rainfall, and $W_{d e f}$ is the water deficit. The $W_{d e f}$, in this case, needs to be covered by irrigation and can be equivalent to the water use multiplied by the efficiency of the system. Thus, the general efficiency of water withdrawals for irrigation (Eff) can be calculated as:

$$
E f f=\frac{W_{\text {def }}}{W_{\text {use }}}
$$

where $W_{\text {use }}$ refers to the water used in the field clusters (Section 2.4).

\subsection{On-Farm Reservoir Volume Modeling}

Even if the previous relations can be observed with remote sensing or global data from the field, storage of water in reservoirs for irrigation is a common practice in Australia. This has two major roles in the irrigation management scheme. The first is to provide buffering to manage possible delays between water orders, water deliveries, and irrigation applications. The second is to store water captured on farms, as regulations require operations to reduce runoff to the environment due to the risk of pesticide movements. Overall, this will allow the operation to reduce the water availability uncertainty and this can obscure the water budget estimates if ignored. Therefore, these storages are important in relation to the irrigation calendar and the water withdrawal dates, adding further information to close the water budget.

In order to estimate the water volume time series in reservoirs, the methodology developed by Fuentes et al. [27] was used. This involves a Bayesian inference method to estimate water volumes in reservoirs and associated uncertainty, using level-volume curves previously calculated from the LiDAR data. Based on the theoretical relationship between surface reflectance and water surfaces, a linear regression between partially flooded areas and a water index developed by Fisher et al. [55] can be used to define a log-likelihood function. After defining suitable flat priors for the parameters of the model, a Markov Chain Monte Carlo (MCMC) approach was used to sample the priors and predict parameter posteriors. Based on this, the volumes and uncertainty can be estimated through the interpolation of level-volume curves. Uncertainties are based on the 16th and 84th percentile of the water-level distributions (which represents one standard deviation) and the selection of a suitable maximum posterior elevation level. More detail on the methodology is provided in Fuentes et al. [27].

\subsection{Soil Moisture Modeling}

To demonstrate how satellite information can be integrated in soil moisture modelling, simulations using MOHID land were developed, assuming no irrigation takes place. This assumption was needed as detailed information about irrigation applications were not available (only bulk water use by month). MOHID Land is part of the modelling system MOHID (http: / / www.mohid.com accessed on 20 February 2022) [56] and is a physicallybased, spatially-distributed, continuous, and variable in time model used to estimate water cycle fluxes in watersheds. Porous media, and all related soil and aquifer physical 
characteristics can be integrated in a MOHID Land implementation. MOHID Land can also couple vegetation, atmosphere, and runoff processes in the overall model structure.

MOHID Land runoff module calculates overland surface runoff over a grid as a function of the water column slopes between adjacent cells, described by the dynamic wave equation [57]. The Manning coefficient and the terrain's elevation are necessary data for Runoff input (Table 1).

Table 1. MOHID Land input parameters used in the soil moisture modelling based on reasonable literature values.

\begin{tabular}{ccccc}
\hline Domain & Symbol & Unit & Description & Value \\
\hline Porous media & $\theta_{S}$ & - & Saturated water content & 0.43 \\
& $\theta_{r}$ & - & Residual water content & 0.03 \\
& $N$ & - & Pore size distribution related term & 1.56 \\
& $A$ & $\mathrm{~m}^{-1}$ & Air entry pressure related term & 3.6 \\
\multirow{2}{*}{ Runoff } & $K_{\mathrm{s}}$ & $\mathrm{m} \mathrm{s}^{-1}$ & Saturated hydraulic conductivity & $2.8 \times 10^{-6}$ \\
& $n$ & $\mathrm{~s} \mathrm{~m}^{-1 / 3}$ & Surface Manning & 0.038 \\
\hline
\end{tabular}

MOHID Land is a model that allows for a very small timestep for detailed modelled results. In fact, water moisture is a property that is characterised by a high variability in time due to the water balance resulting from the precipitation (rainfall) input and evaporation output. For this property, a small timestep is required for a more detailed characterisation of the water moisture behaviour during the modelled period.

Although the water deficit component uses monthly aggregate precipitation datasets as input, for a MOHID Land implementation daily or hourly rainfall values are recommended. With this in mind, the GPM version 6 rainfall was used as a 30-min time series.

Furthermore, the reference evapotranspiration was used as a monthly average dataset (mm per day). Because reference evapotranspiration has a lower monthly variability than rainfall, no further data time interpolation was performed for this property.

The porous media module calculates water fluxes in the soil medium, including water transport due to the balance between pressure (gravity and suction) and resistance through the medium, infiltration, evaporation, and the groundwater boundary water balances [58,59]. Therefore, the module requires physical properties of modelled soil. In MOHID Land, the equation that describes the flow through soil is the Buckingham-Darcy equation $[60,61]$.

For the soil moisture estimates, and in the absence of observed data, as an example, the modelling focused on site $b$ only. The soil geometry was characterised by a constant depth of $2 \mathrm{~m}$ across the grid, divided between 5 layers with variable depths (Figure 2). Typically, as illustrated below, the upper soil was characterised with thinner layers and the lower soil with thicker layers. Layers can then be aggregated into soil horizons with different physical properties. The MOHID Land implementation described here, however, assumes a constant soil type for all grid cells and all layers across the soil profile. In the absence of detailed soil data, the soil here was characterised as a loam soil.

Initial water moisture was set to field capacity for each layer, which, for the current implementation,meant a water content from the top layer to the bottom layer of $0.29,0.19$, $0.17,0.16$, and $0.16 \mathrm{~m}^{3}$ of water per $\mathrm{m}^{3}$ of soil. Initial water moisture was constant for every cell across the grid.

Considering that the first layer has a high variability, due to the fast reaction to precipitation, lower depths have lower variability and slower changes. The 2D results of the simulations are presented for the 3rd layer because tit balances both distinct behaviours. 


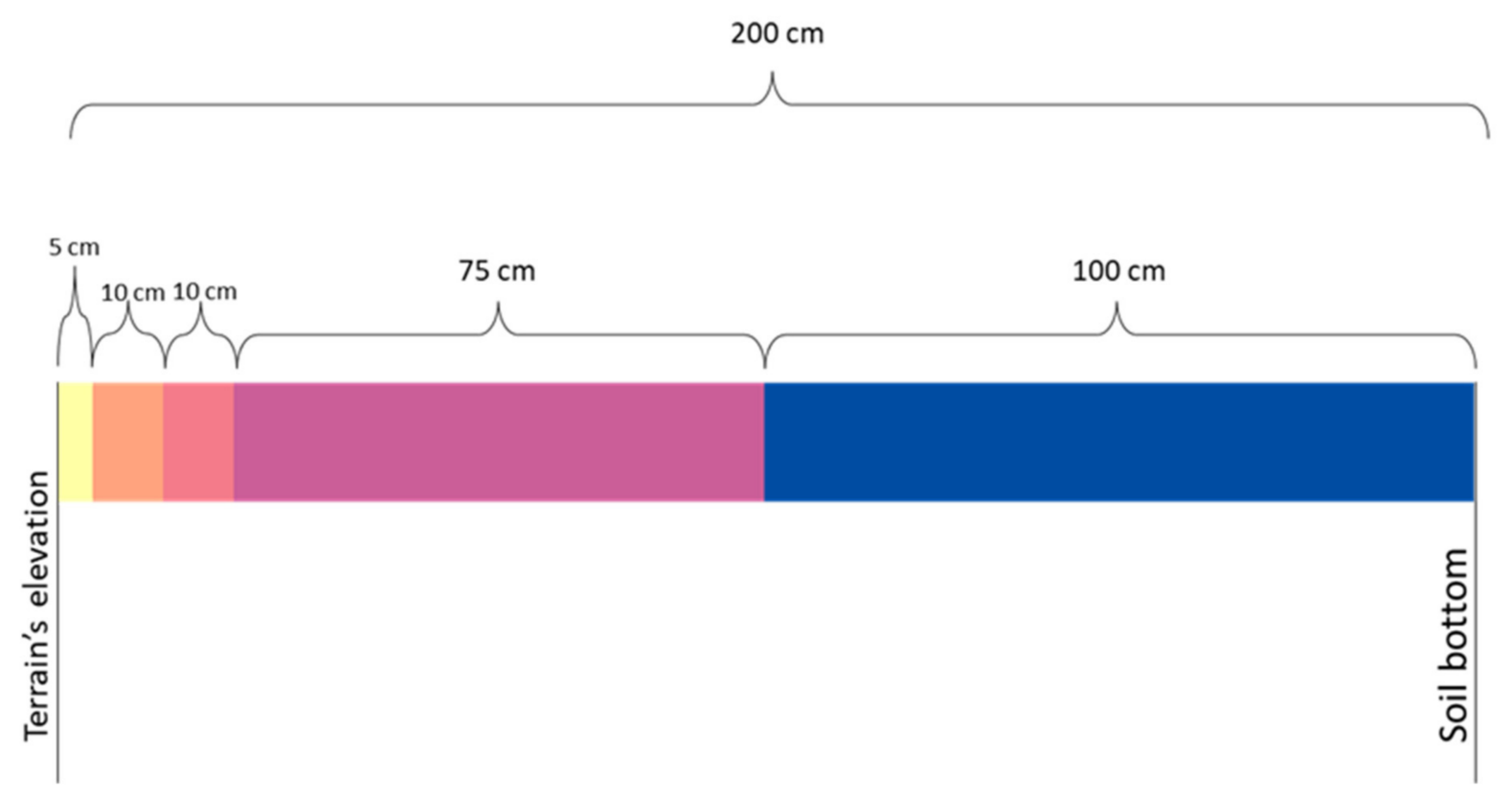

Figure 2. Case study soil geometry.

\section{Results}

\subsection{FAO Penman-Monteith ETr}

Average daily global reference evapotranspiration rasters for every month were developed, given the global scale of the datasets used (Figure 3). The range of mean daily values for July 2017 varied between 0 and $14 \mathrm{~mm}$ day $^{-1}$, with the maximum values occurring in arid areas of the mid latitudes.

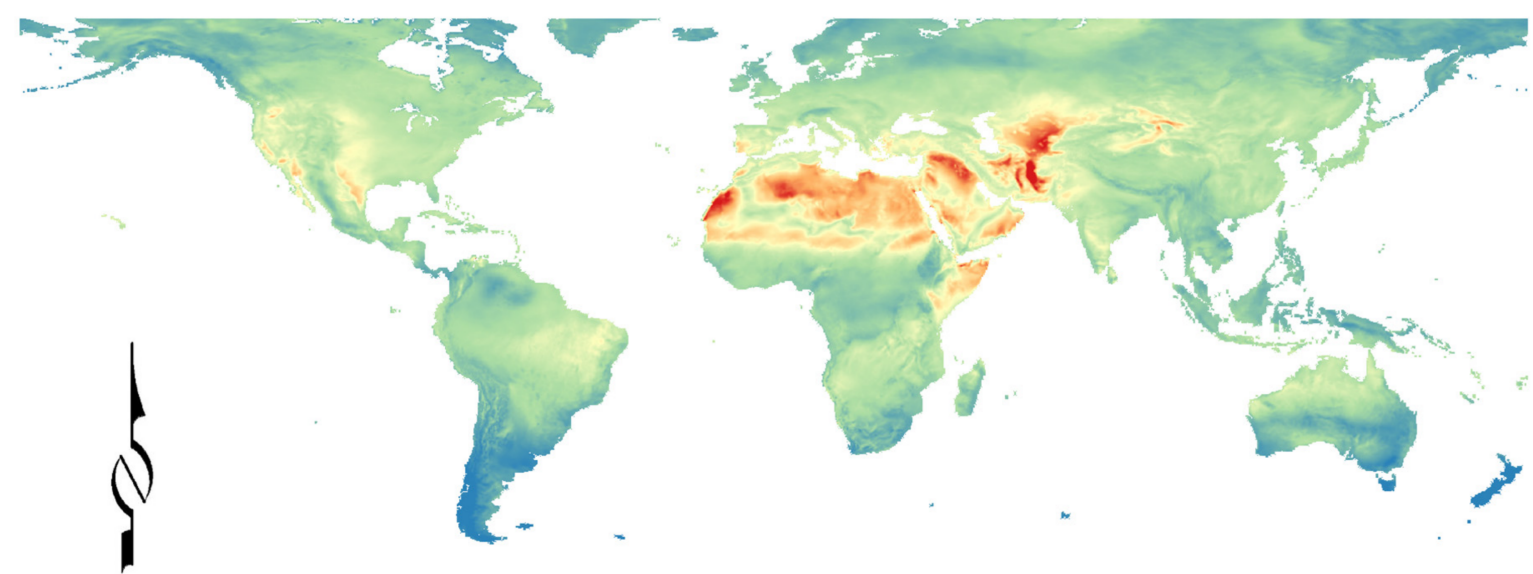

\section{Reference evapotranspiration}

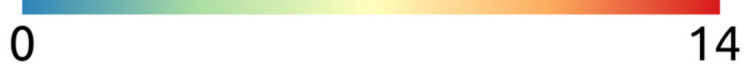

Figure 3. Average daily reference evapotranspiration estimated for July $2017\left(\mathrm{~mm} \mathrm{day}^{-1}\right)$ used for the evapotranspiration estimates.

\subsection{ETLook and CMRSET AET Estimates}

The first results presented are mean daily estimates of actual evapotranspiration (AET) per month at the field scale for both sites, which are shown in Figure 4. On the left, the results of the CMRSET algorithm [51] are presented, and on the right the results of the ETLook algorithm are shown. The values of AET calculated using the energy balance approach in ETLook [37] are generally lower than the AET estimates in CMRSET. The results from ETLook also demonstrate a different temporal pattern, with the peak in 
mean daily ET occurring in February, compared with January in the CMRSET algorithm. The difference is likely explained by the fact that the crop factor approach in CMRSET underestimates the resistance due to stomatal closure and the variation in vegetation types, which the energy balance method picks up as it is more locally adjusted. As a result, the estimates of the CMRSET algorithm are mainly radiation driven. The single national regression in the crop factor approach does not directly scale to the field and would have to be adjusted for crop types.
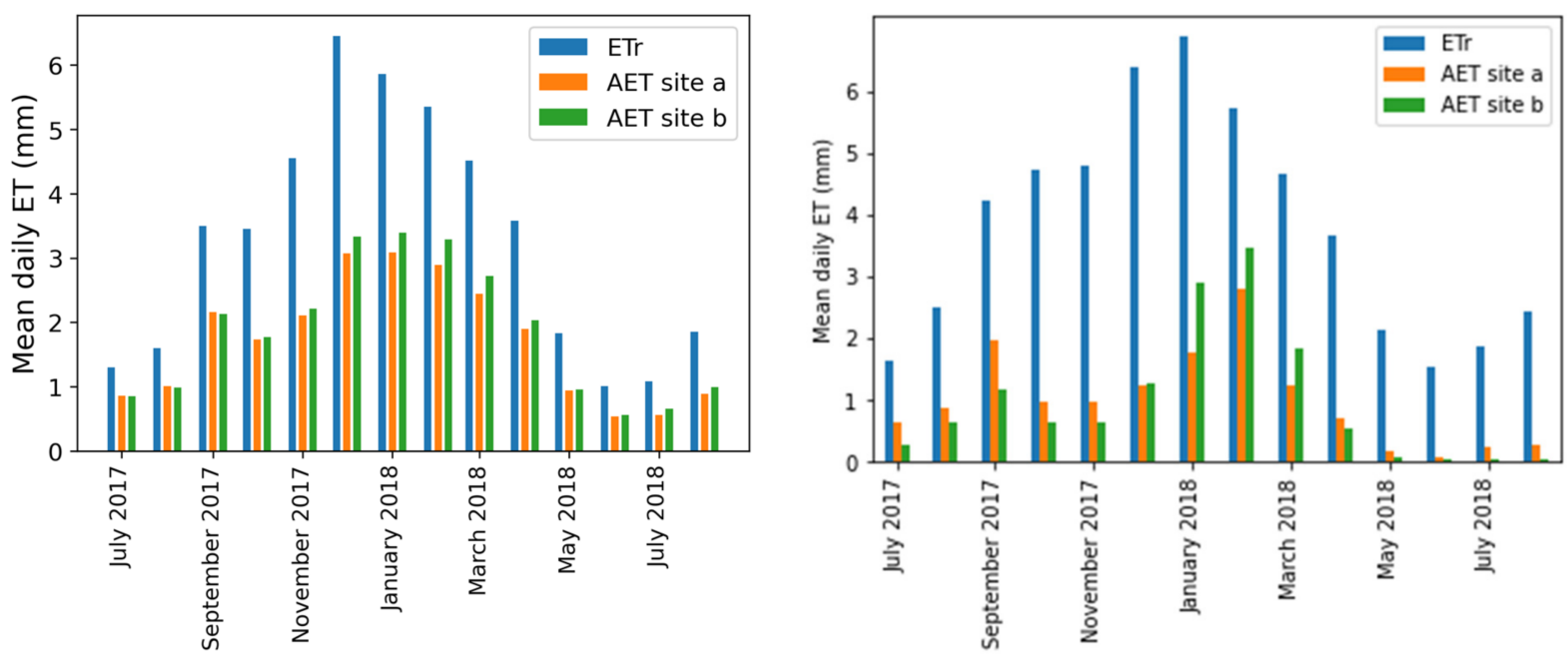

Figure 4. Average mean daily values by month for reference ET (Etr, blue bars) and AET for site $\mathbf{a}$ (orange bars) and site $\mathbf{b}$ (green bars) using the CMRSET approach (left) and ETLook algorithm (right) indicating much lower estimates of AET from the ETLook algorithm compared with the CMSRET approach.

Scaling the mean daily values to monthly visualises the monthly spatial images (Figures 5 and 6). This clearly indicates the spatial variability of AET across the sites associated with different land cover (crops) and the irrigation scheduling. The monthly sums, for those fields that are irrigated, were much greater in January-March 2018 for the ETLook algorithm compared with the CMRSET algorithm. This is, again, because the ETLook algorithm adjusts better to local variation than the global CMRSET algorithm and is less driven by the radiation signal. The CMRSET estimates picked up some variation in AET in space due to differences in the vegetation greenness, which influences the crop factor estimate (Equation (1)). However, in August-October 2017 at site a, there were spatial variations in greenness, reflected in the Kc estimates, but this translates in limited spatial variations in AET due to low radiation. In contrast, the ETLook results indicated a stronger spatial pattern.

\subsection{Site Water Balance and Efficiency}

Summarising these results to estimate the water balance for each site (Tables 2 and 3) shows accumulated annual rainfall of $4139.2 \mathrm{~m}^{3} \mathrm{ha}^{-1}$ at site $\mathbf{a}$, and $4199.2 \mathrm{~m}^{3} \mathrm{ha}^{-1}$ at site $\mathbf{b}$ for the $2017 / 2018$ cropping season. The accumulated AET using the CMRSET algorithm was $6686.7 \mathrm{~m}^{3} \mathrm{ha}^{-1}$ for site $\mathbf{a}$, and $7294.4 \mathrm{~m}^{3} \mathrm{ha}^{-1}$ for site $\mathbf{b}$. Using the ETLook algorithm, the estimates of accumulated AET were $4051.9 \mathrm{~m}^{3} \mathrm{ha}^{-1}$ for site $\mathbf{a}$, and $4066.0 \mathrm{~m}^{3} \mathrm{ha}^{-1}$ for site b. Clearly, the annual estimates for ETLook were, again, lower than for the CMRSET algorithm. As a result, the overall cumulative deficits for the ETLook estimates were quite small, suggesting irrigation might not be needed if rainfall were to be harvested effectively. Using the reported water use by NSW DPIE, the calculated efficiencies were site $\mathbf{a}=74 \%$ (no active on-farm dam), efficiency site $\mathbf{b}=38.3 \%$ (active on-farm dam) (CMRSET). The efficiencies for ETLook were, of course, very small, and due to the negative estimates of the overall deficit not easily calculated. 


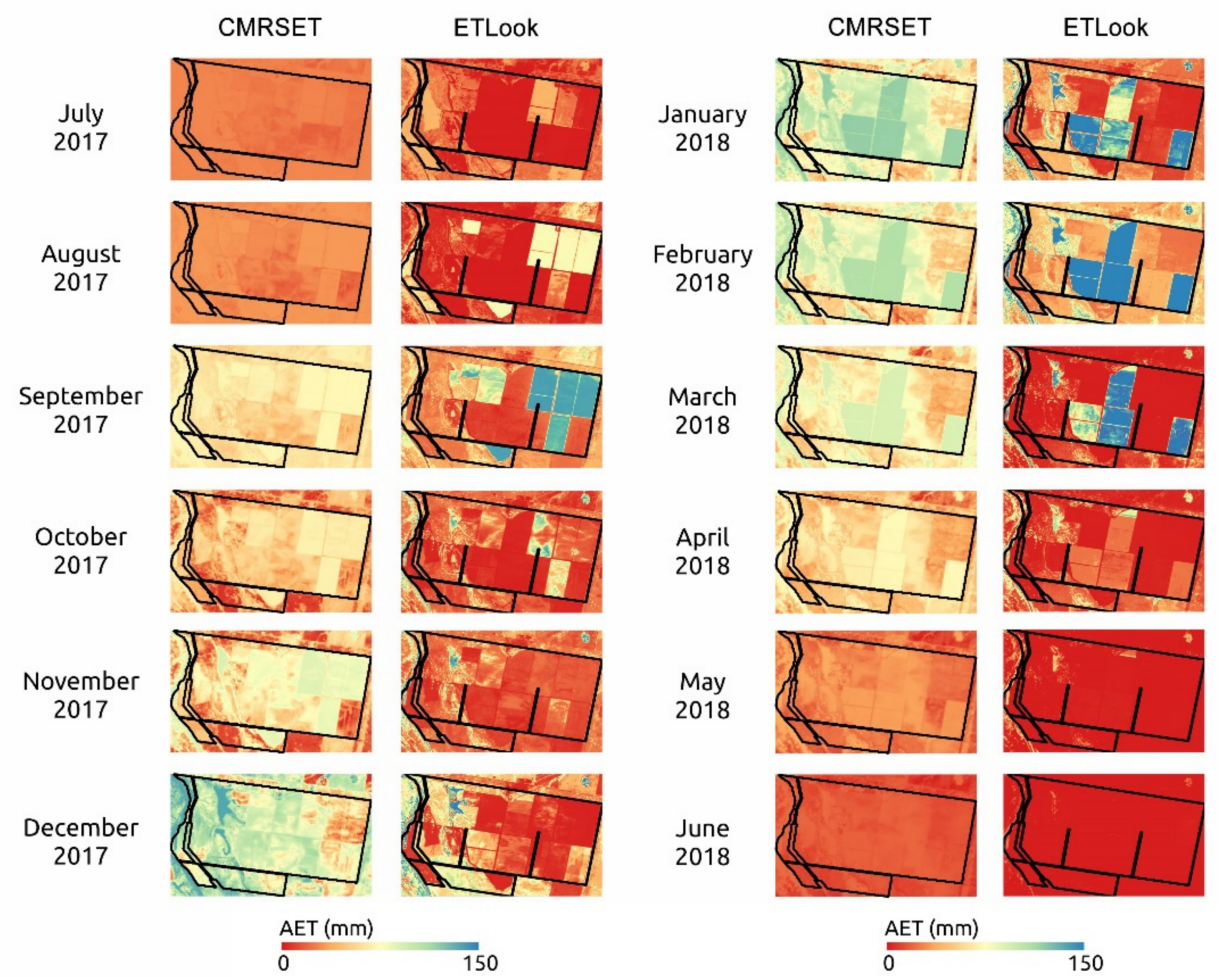

Figure 5. Monthly sum of AET for study site a using the CMRSET approach and ETLook algorithm. Colour scale for predicted AET ranges from 0-150 mm.

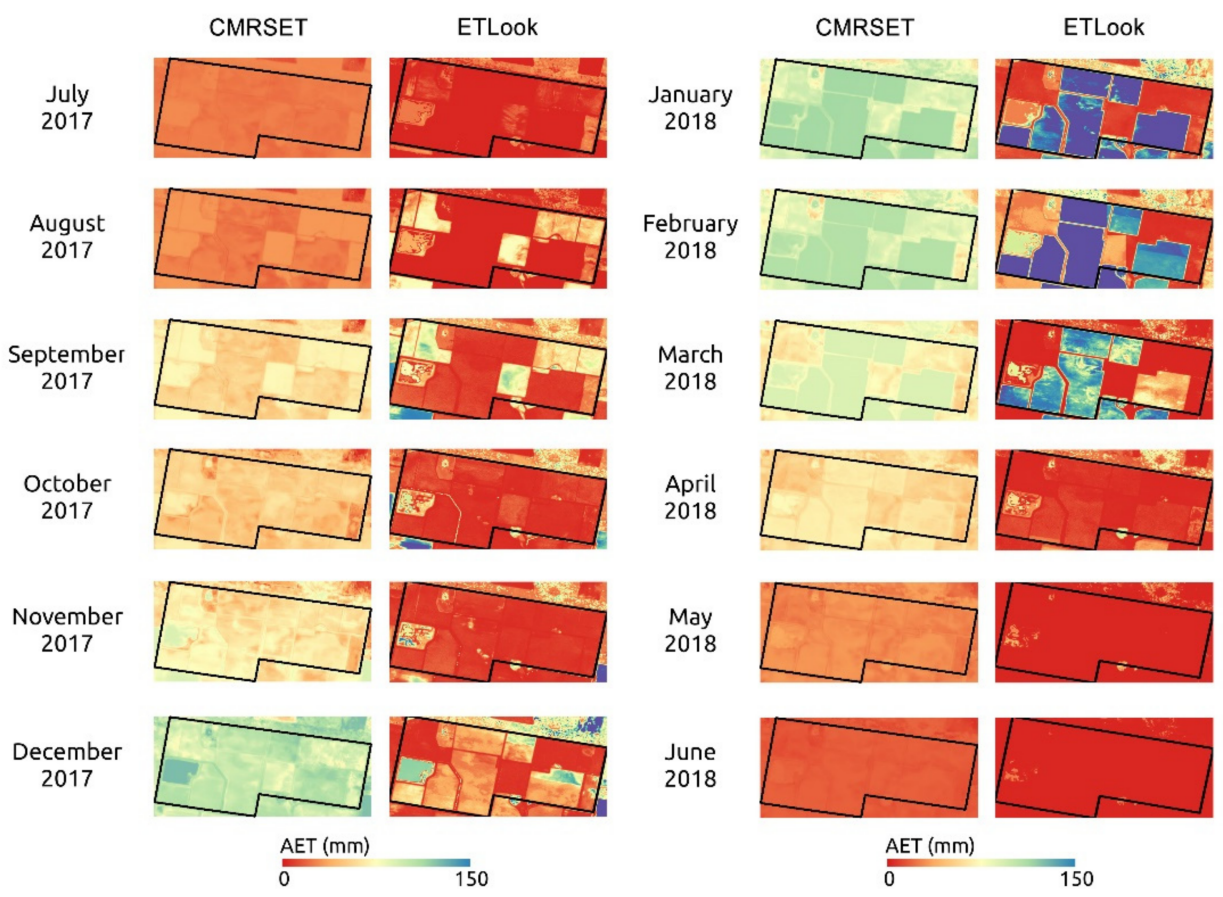

Figure 6. Monthly sum of AET for study site $\mathbf{b}$ using the CMRSET approach and ETLook algorithm. Colour scale for predicted AET ranges from 0-150 $\mathrm{mm}$.

This points to a difficulty of calculating efficiencies based on cumulative rainfall for a month and ignoring any possible runoff losses. Clearly in some of the months with high rainfall totals, almost none of this rainfall was captured for effective evapotranspiration. As a result, it is also difficult to calculate efficiencies by month. 
Table 2. Water balance $\left(\mathrm{m}^{3} \mathrm{ha}^{-1}\right)$ for study sites a based on CMRSET and ETLook estimates of AET (Demand).

\begin{tabular}{ccccccc}
\hline & & & \multicolumn{2}{c}{ CMRSET } & \multicolumn{2}{c}{ ETLook } \\
\hline Month & Rain & Use & Demand & Deficit & Demand & Deficit \\
\hline July 2017 & 182 & 10 & 261 & 79 & 197 & 15 \\
August 2017 & 248 & 8 & 302 & 53 & 272 & 24 \\
September 2017 & 31 & 37 & 624 & 593 & 591 & 560 \\
October 2017 & 828 & 372 & 520 & -308 & 299 & -529 \\
November 2017 & 731 & 212 & 621 & -111 & 292 & -439 \\
December 2017 & 399 & 620 & 906 & 507 & 380 & -18 \\
January 2018 & 456 & 1278 & 942 & 486 & 554 & 98 \\
February 2018 & 435 & 721 & 771 & 336 & 785 & 350 \\
March 2018 & 457 & 71 & 725 & 268 & 385 & -72 \\
April 2018 & 210 & 18 & 562 & 353 & 215 & 5 \\
May 2018 & 128 & 75 & 293 & 164 & 58 & -70 \\
June 2018 & 34 & 22 & 162 & 128 & 22 & -12 \\
\hline Total & 4139 & 3444 & 6687 & 2548 & 4052 & -87 \\
\hline
\end{tabular}

Table 3. Water balance $\left(\mathrm{m}^{3} \mathrm{ha}^{-1}\right)$ for study site $\mathbf{b}$ based on CMRSET and ETLook estimates of AET (Demand).

\begin{tabular}{ccccccc}
\hline & & & \multicolumn{2}{c}{ CMRSET } & \multicolumn{2}{c}{ ETLook } \\
\hline Month & Rain & Use & Demand & Deficit & Demand & Deficit \\
\hline July 2017 & 189 & 24 & 258 & 68 & 87 & -103 \\
August 2017 & 246 & 20 & 285 & 39 & 199 & -47 \\
September 2017 & 34 & 87 & 606 & 572 & 357 & 323 \\
October 2017 & 839 & 873 & 532 & -307 & 195 & -644 \\
November 2017 & 745 & 497 & 655 & -89 & 198 & -547 \\
December 2017 & 426 & 1453 & 1046 & 620 & 399 & -27 \\
January 2018 & 463 & 2996 & 1065 & 602 & 895 & 433 \\
February 2018 & 429 & 1690 & 921 & 492 & 973 & 543 \\
March 2018 & 438 & 166 & 842 & 404 & 566 & 128 \\
April 2018 & 211 & 42 & 613 & 402 & 161 & -50 \\
May 2018 & 132 & 175 & 302 & 170 & 25 & -107 \\
June 2018 & 48 & 52 & 170 & 123 & 11 & -37 \\
\hline Total & 4199 & 8074 & 7294 & 3095 & 4066 & -133 \\
\hline
\end{tabular}

\subsection{Reservoir Volume Estimates}

The difference in the water use between site $\mathbf{a}$ (with no active farm dam) and site $\mathbf{b}$ (with an active farm dam) is also interesting. Using the Copernicus satellite data, the volumes in the farm dam (and associated uncertainties) can be estimated (Figure 7). Noticeable is the sharp increase in the farm dam volume after November 2017. At first glance, this appears to be related to the large water use figures for the cluster in December-February at site $\mathbf{b}$ (Table 3). However, it also follows the rainfall surplus in October and November 2017 (Tables 2 and 3). In other words, the filling of the dam could be a combination of surplus runoff and ordered water stored on farm, which is subsequently drawn down for irrigation use. Note that in the images on the top row in Figure 7, the dates are not equally spaced. In the CMRSET algorithm, water storage translates into high water losses (evaporation, most probably) especially between November and February, which might explain the reduction in water efficiency for site $\mathbf{b}$.

\subsection{Soil Moisture Estimation}

The spatial distribution of the soil moisture, represented as the relative water content, in the 3rd modelled layer of the soil, i.e., at $25 \mathrm{~cm}$ of soil depth, is highlighted in Figure 8. Each image is a snapshot of the layer's relative water content for the last time increment of 
each simulated month. The relative water content scales the actual soil moisture between 0 (very dry) and 1 (saturated).
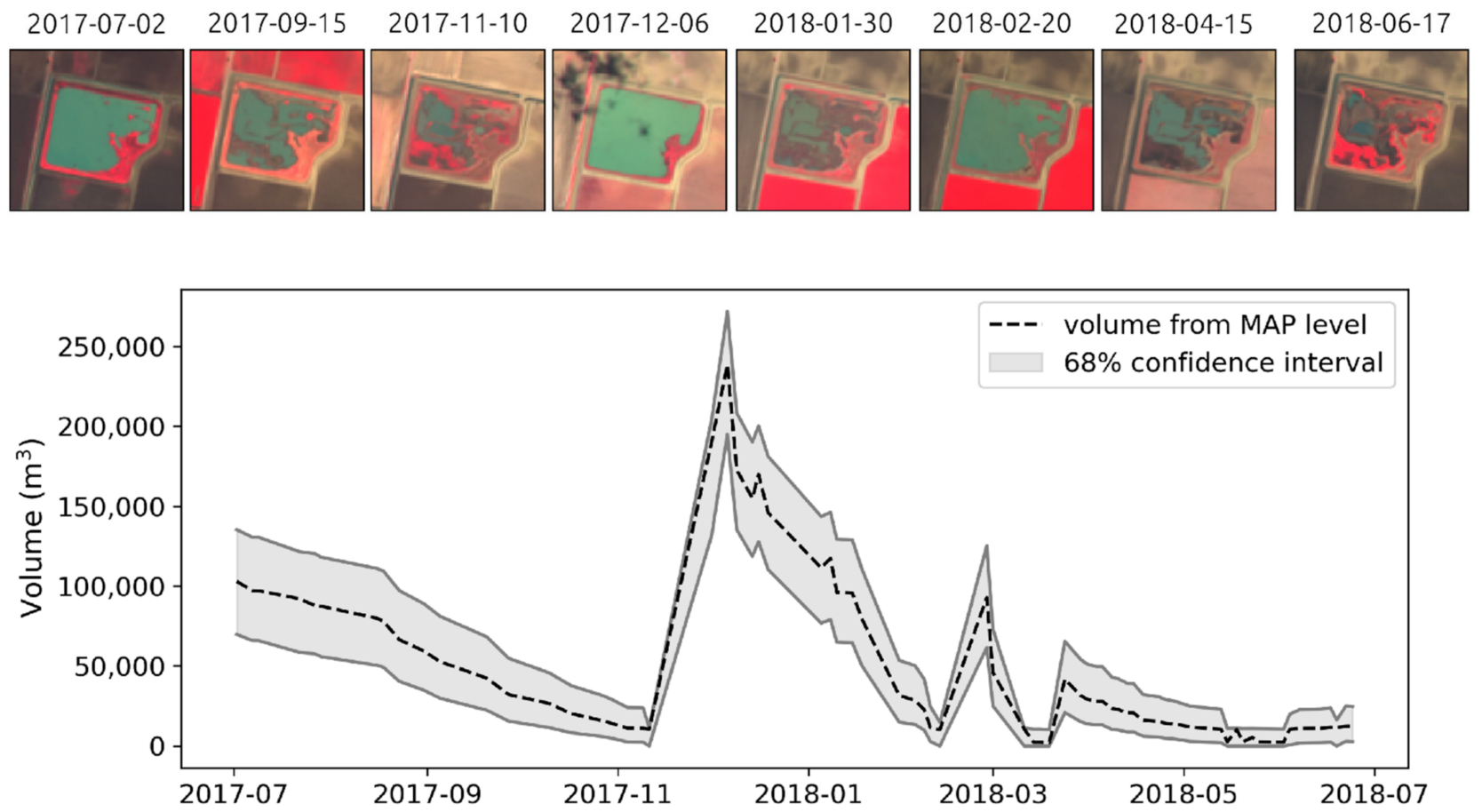

Figure 7. Top: image time series of the water surface in the reservoir at site $\mathbf{b}$. Bottom: mean modeled reservoir volume time series (dashed line) in study site $b$ and associated uncertainties (grey shading for $68 \%$ confidence interval). The top figure indicates time snapshots of the satellite data showing the different surface water coverages in the reservoir.

October 2017 indicated the highest spatial variability in soil moisture (Figure 8). This is most likely due to the high rainfall in October (Tables 2 and 3) combined with the spatial variation in the predicted evapotranspiration. This is not as visible in Figures 5 and 6 as the AET in those figures is the cumulative monthly AET, while in the soil moisture we observed a snapshot of the storage at the end of the month. The high rainfall for the month explains the overall higher water content across the domain's grid.

September and December 2017 had an overall lower soil moisture across the grid following lower rainfall during August and September (Tables 2 and 3), while the relative soil water content in December 2017 can be associated with the higher rate of evapotranspiration during that month.

For an even more local analysis and a detailed time series view, three grid cells with different crop coefficient values are highlighted (Figure 9).

The time series of the simulated relative water content at $25 \mathrm{~cm}$ depth for the selected study points is highlighted in Figure 10, combined with the precipitation (rainfall) time series. This matches the common scale used to observe crop water productivity $[4,31]$. However, in this case the results are based on a landscape level gridded model, rather than a point scale model, which ignores any lateral flow effects. Figure 10 shows a detailed view of the relative water content increases and decreases as a response to wet and dry periods. The declines in relative water content followed typical exponential declines related to the soil water-retention characteristics in MOHID Land. 


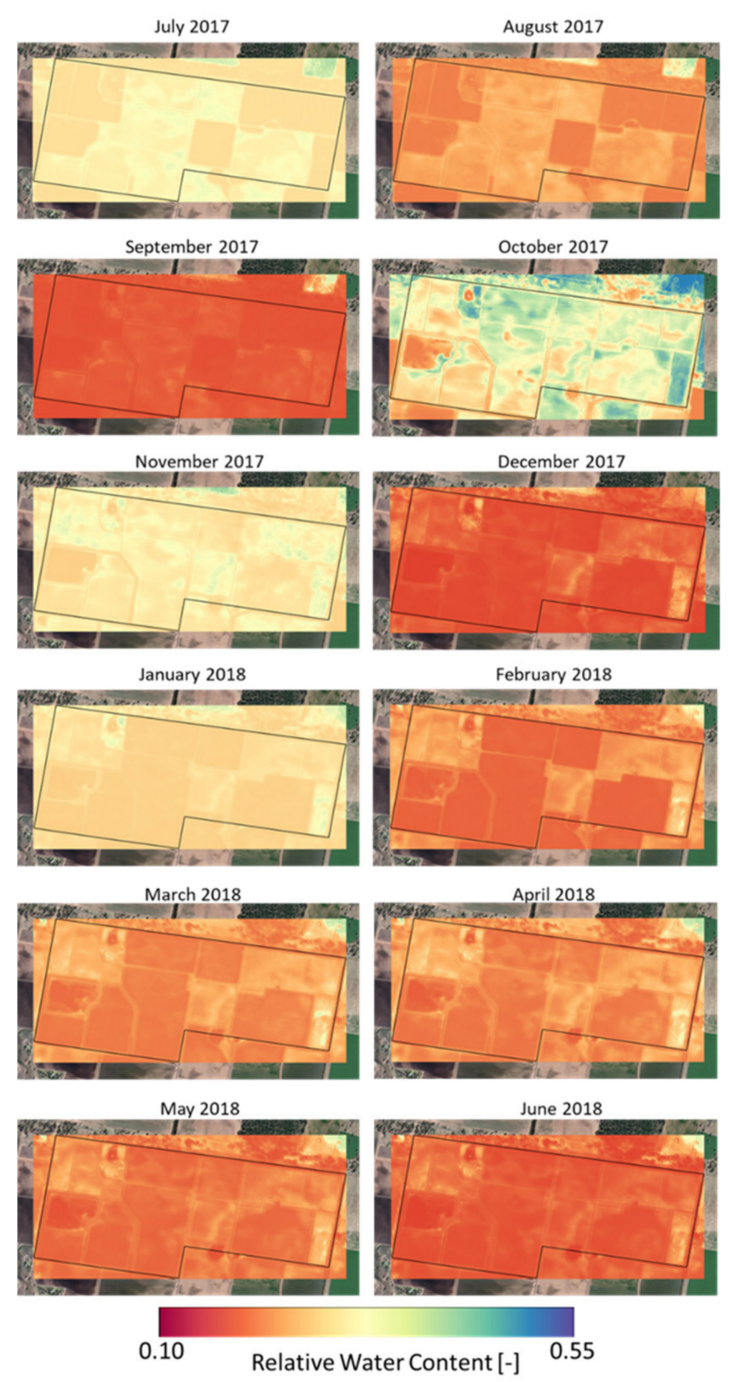

Figure 8. MOHID Land porous media output of relative water moisture at $25 \mathrm{~cm}$ soil depth (from the terrain's elevation) for the last time period of each month from July 2017 to June 2018 for Site $\mathbf{b}$.

Of course, in this case, the difference between the three points in Figure 10 is mainly driven by crop coefficients (Figure 9), as the soil properties were uniform across the grid and no irrigation applications were assumed. For example, during October 2017, a high precipitation event over a long time period occurred, which resulted in a higher relative soil water content variability between the three points, as the different crop coefficients caused the AET to respond differently to the increased wetness for the three points. However, in November 2017 a high precipitation event during a short time frame occurred. This, coupled with the similar crop coefficient in November and December 2017, caused the variability in the relative water content to decrease substantially.

Finally, Figure 11 shows a Time-Depth Graph for the three selected study locations. The figures clearly show the variability of soil water content due to precipitation. While the first layer $(5 \mathrm{~cm})$ reacted very fast to rainfall events and drying events, the bottom layer $(200 \mathrm{~cm})$ had much lower variability, with the relative soil water content continuously decreasing throughout the simulated period. Considering that the simulation started at field capacity, this decrease shows that the soil has depleted due to the deficit between precipitation and evapotranspiration. Ideally, these results would be validated using observed soil moisture observations in the field, but these are currently not available. 

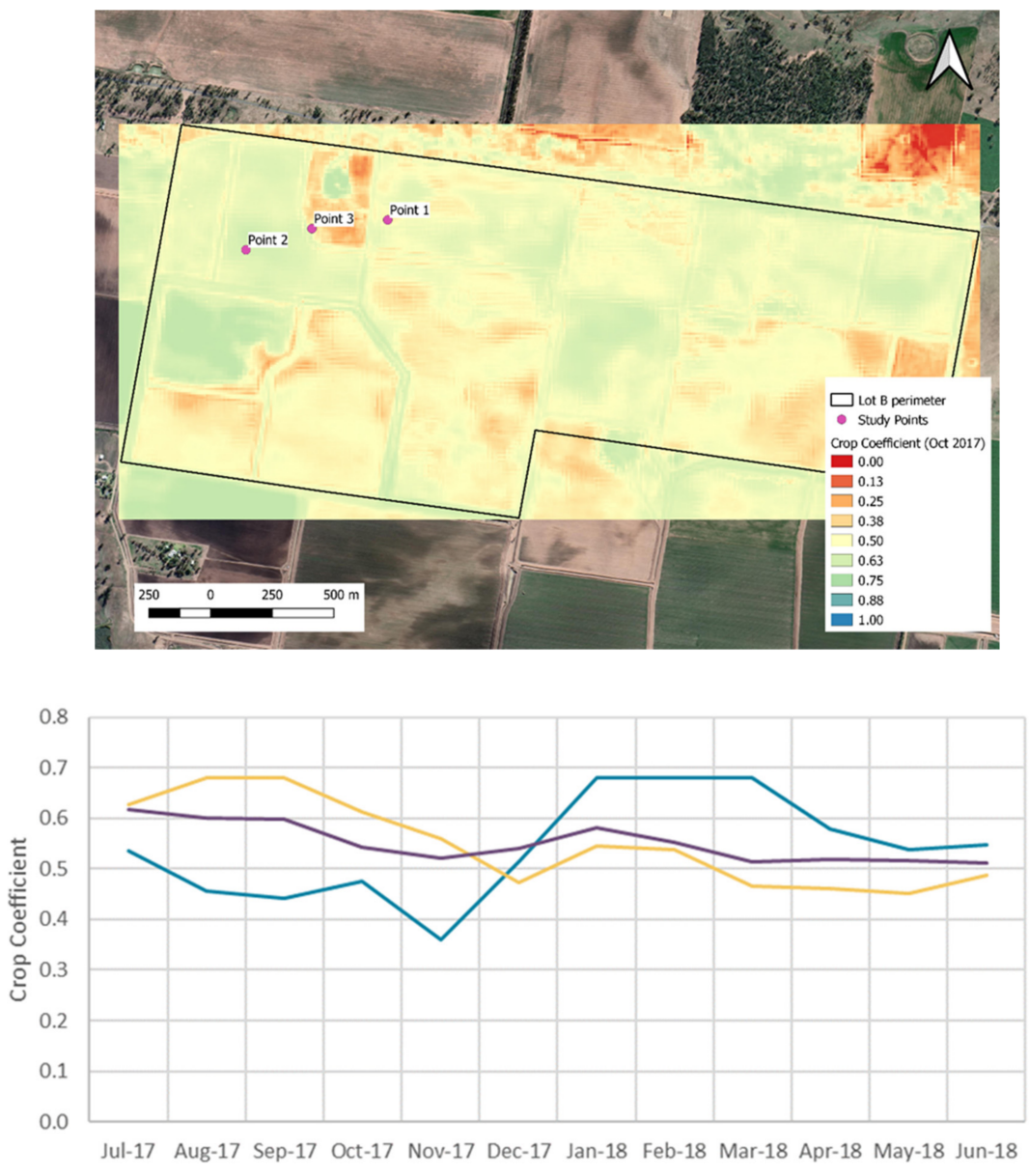

$$
\text { —Point } 1 \text { Point } 2 \text { Point } 3
$$

Figure 9. (Top) Map of the position of three selected study points overlaying the satellite detected crop coefficient for the month of October 2017 in site b. (Bottom) Sentinel 2 data-derived (Equation (1)) crop coefficient time series from July 2017 to June 2018 for the three selected study points at site $\mathbf{b}$.

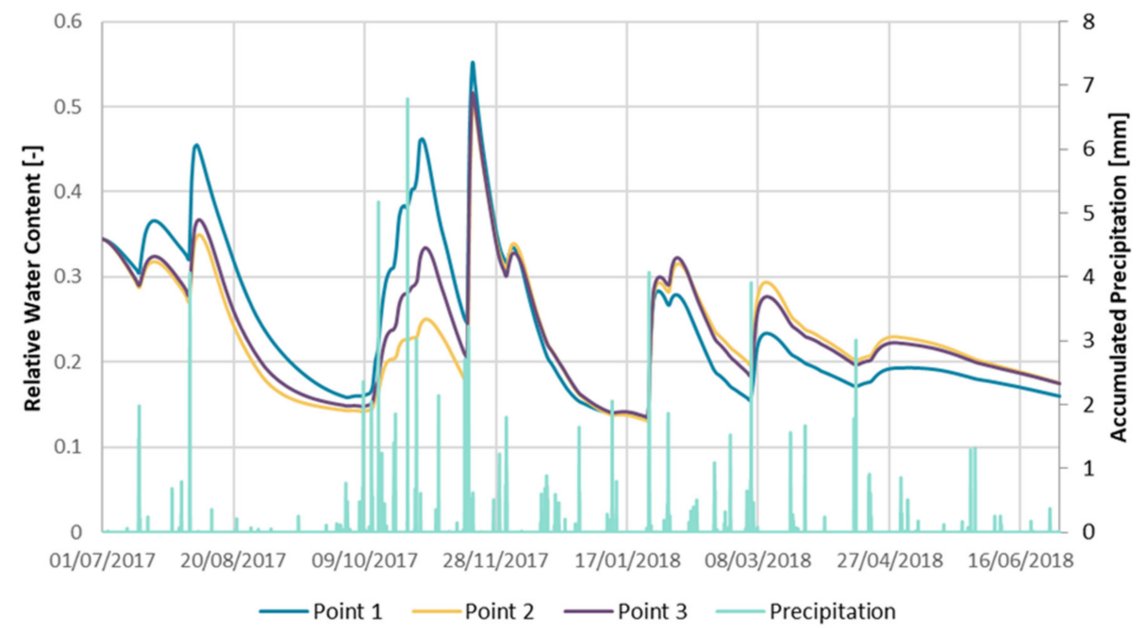

Figure 10. Relative soil water content (-) time series from 1 July 2017 to 30 June 2018, and MOHID Land accumulated precipitation (mm) (rainfall) during the same period for locations 1, 2, and 3 (Figure 9). 

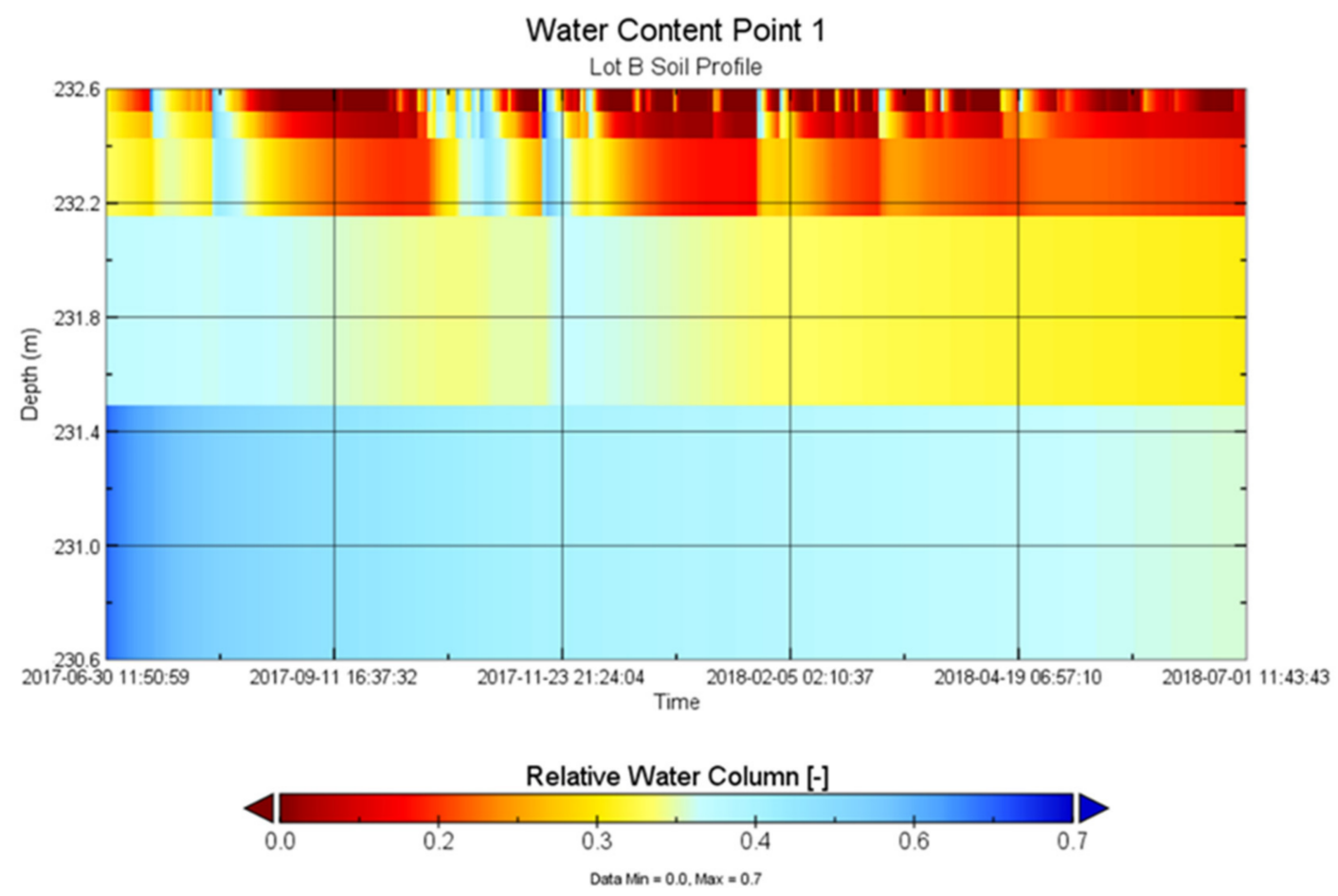

Water Content Point 2
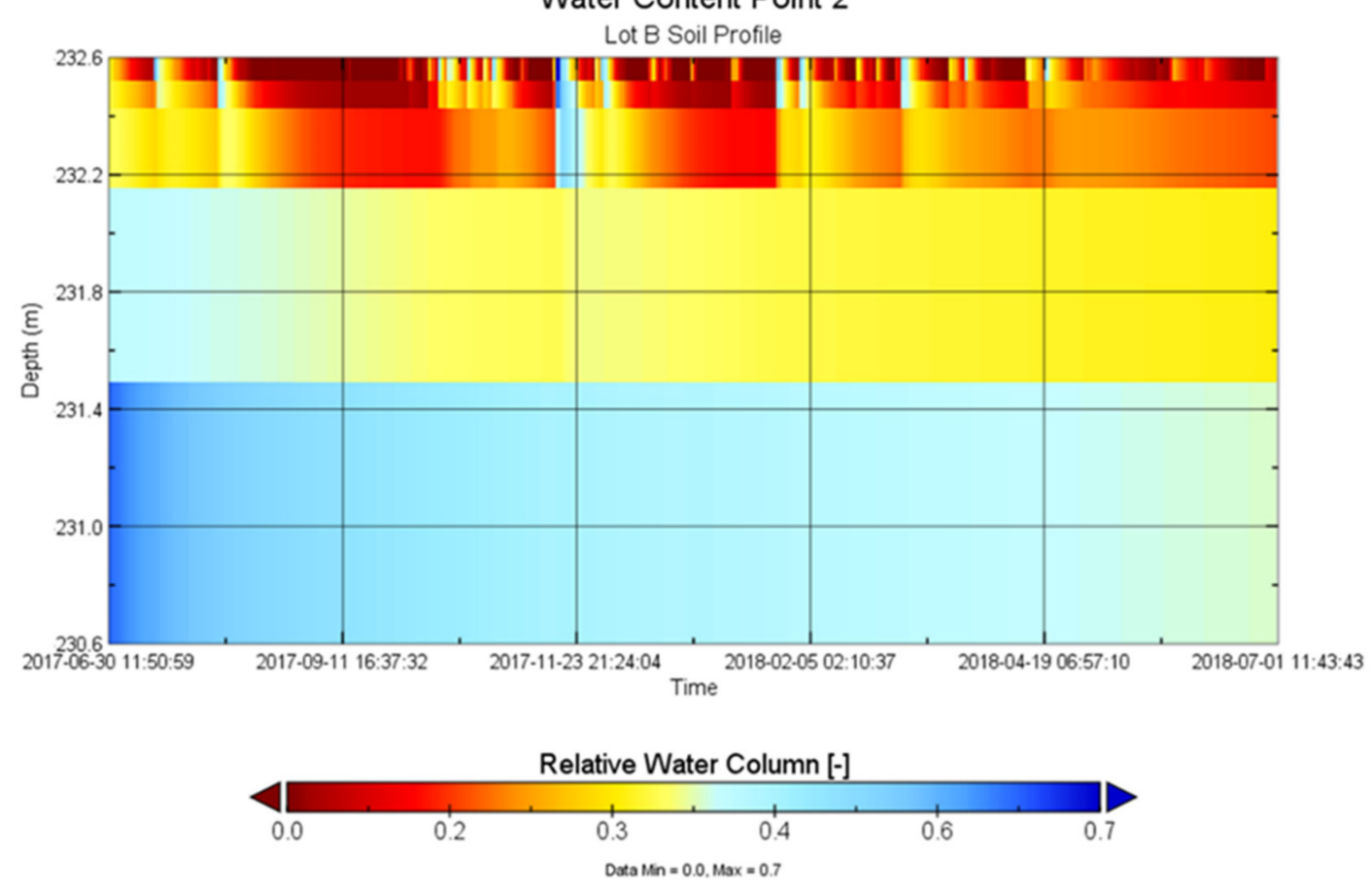

Figure 11. Cont. 


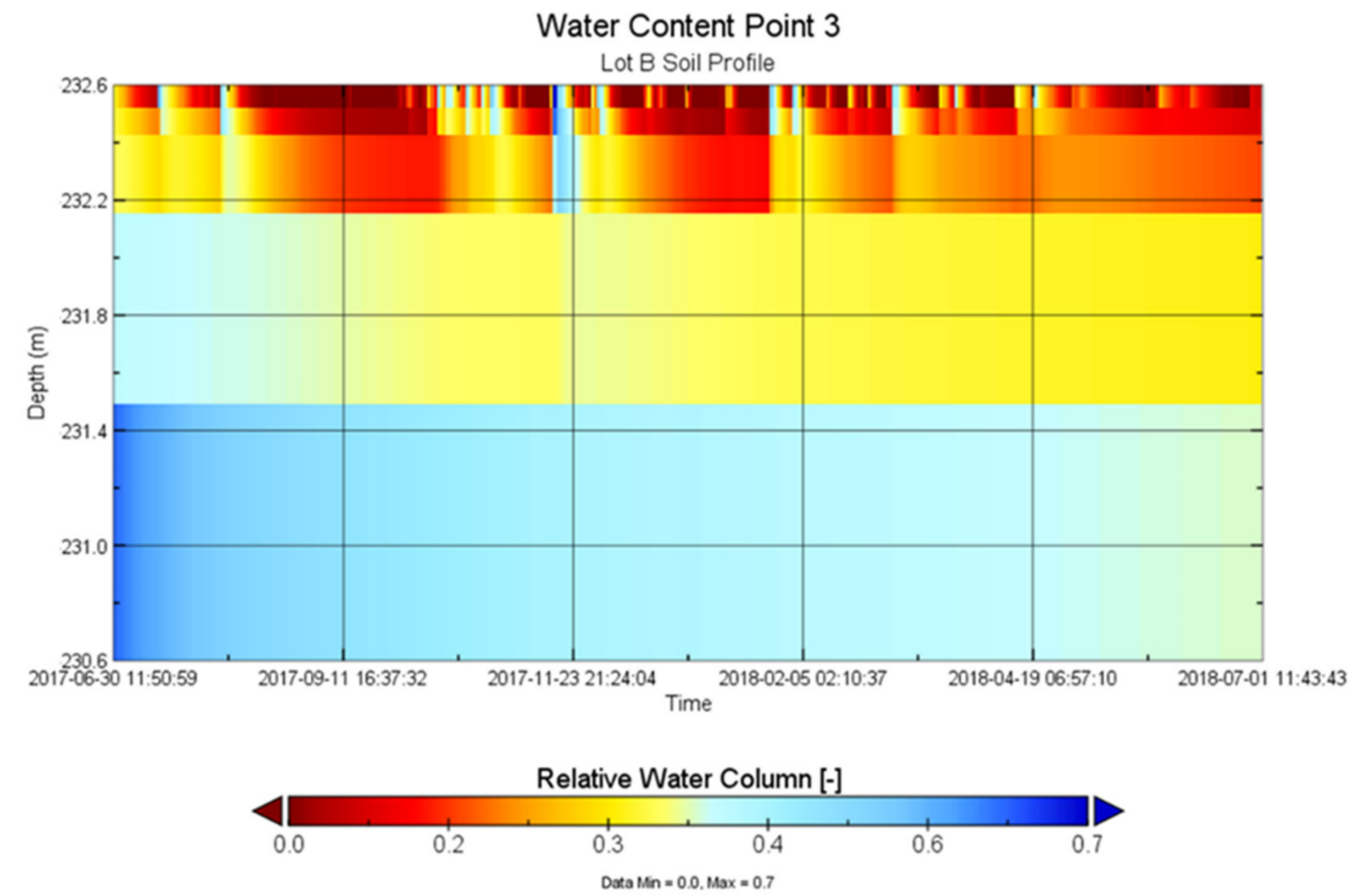

Figure 11. Time-depth graphs of the Relative Water Content (-) across the soil profile for the three selected study points (top: location 1, middle: location 2, bottom: location 3). Note that "Depth" is in elevation above Australian sea level (ASL).

\section{Discussion}

\subsection{General Discussion}

In this paper, we demonstrated that it is now feasible to observe several water balance components at field scales using satellite data, complemented by modelling at finer scales. Evapotranspiration, soil moisture, and volumes of water in farm dams can all be observed, and there are often several approaches to estimate the same property, e.g., [31]. Soil moisture has always been difficult, as most of the remote sensing can only investigate the top few centimetres of soil, and this is mostly at very large scales [41,62]. As a result, the future might be using satellite observation of the top layers, augmented by soil moisture modelling (as presented here and [62]), or using downscaling (Fuentes, Padarian, Vervoort, Towards near real-time national-scale soil water content monitoring using data fusion as a downscaling alternative, submitted to Journal of Hydrology). This also has the potential resolve the differences between the energy balance and crop-factor-based approaches highlighted in this paper.

However, given that at least daily rainfall data exists in most places (and in Australia, several detailed gridded products exist), closure of the water balance is eminent: rainfall inputs, evapotranspiration outputs, and changes in storage can all be observed at a finegridded scale. Assuming runoff losses in irrigated systems are negligible, closing the water balance at the field and farm scale is within reach.

Before we reach this point there are still several challenges, particularly if this needs to be extended to many global locations. The first is the availability of input data at sufficient detail in time and space. While the satellite data are widely available, and ET estimates can be derived without any ancillary data, this is not the case for several of the other water balance elements, as was demonstrated here. For example, the current implementation to quantify farm dam volumes [27] relies on the 1-m digital elevation model (DEM) that is available for parts of Australia. Applying the same algorithm to a coarser scale DEM will result in a significant deterioration of the accuracy as the actual depth of the farm dam cannot be estimated accurately. In the soil moisture modelling presented here, several 
assumptions had to be made simply because detailed data for soil properties and irrigation applications were not available. However, despite these assumptions, modelling combined with satellite information will deliver estimates of sufficient accuracy that water balance calculations can be performed. For example, the modelling of soil moisture suggests that an increase of roughly $0.2 \times 0.2 \times 0.25 \times 10,000=100 \mathrm{~m}^{3} \mathrm{ha}^{-1}$ as a result of the rainfall in November, or approximately $10-15 \%$ of the monthly rainfall total, with similar amounts for the earlier month. This explains some of the mismatch in Tables 2 and 3, as this means that the "effective rainfall" contributing to the deficit is a lot lower, hence explaining the additional water use in many months.

The second challenge leading from the above analysis is the assumption that runoff is negligible, or that all rainfall is somehow used for crop production. Clearly this is not the case, as Tables 2 and 3 and the above analysis demonstrate. With limited data on field scale runoff losses reported, this currently can only be resolved by modelling, or estimating using the water balance closure as a constraint. As runoff will vary globally depending on soil type, crop cover, and rainfall intensity, this remains a problem that can only be approached using modelling.

The third major and most significant challenge is to progress from water balance components to crop productivity, and for this, accurate predictions of yields are an important step. There are two elements to this: the first is crop detection [63], and the second is the prediction of actual yields. Currently, the approach is to predict yields directly [64,65] as, particularly in Australia and the US, more and more growers use precision agriculture and yield monitoring. However, predicting it from gross primary production (through evapotranspiration) would be more interesting, but this is limited by the variation in the conversion from biomass to yield between crops and locations.

The fourth major challenge is around validation data. A recent review by Massari et al. [12] highlighted that accurate determination of irrigated water use remains challenging. They particularly highlighted the lack of validation data that are available to verify the predictions. However, in the end, accurate predictions of water productivity are also in the interest of irrigators as water accounting can offer important clues for improving water use efficiency of irrigated systems.

\subsection{How Do We Achieve Accurate Water Footprint and Crop Water Productivity Estimates at All Global Locations?}

Arguably, there is already an existing global crop water productivity platform provided by the FAO: WaPOR V2 [14,22]. This product provides estimates of crop water productivity based on remotely sensed ET, crop phenology, and biomass production/harvest indices at $250 \mathrm{~m}$ to $1 \mathrm{~km}$ scales. In terms of water use efficiency, this provides the Gross Production Water Use and Net Production Water Use indices [14]. However, as shown in the case study, while using ET can provide estimates of individual crop productivity, it cannot derive whole farm water footprints and whole farm irrigation efficiency (WFEI, [66]). For this, we still need understanding of the remaining water fluxes and storages at each enterprise. So far, this has only been achieved through detailed surveys (e.g., [66]).

In the WaterSENSE project, the concepts related to WaPOR are combined with detailed quantification of other components, but this remains challenging. We have the remote sensing data and much of the ancillary data, but not always at the required spatial and temporal scales. Collection of validation data remains challenging, as there is a plethora of different spatial product offerings, especially in the evapotranspiration and vegetation remote sensing area. In addition, the commercialisation of irrigation management has resulted in a decline in government investment in irrigation research. Convincing local producers and irrigators to invest time and possibly money in collecting local data without direct outcomes can therefore be challenging, even if this will in the future result in improved irrigation management [12]. However, to be able to quantify water footprints and whole farm water use efficiency at any location in the world, there is a need to combine research efforts and connect the available spatial and temporal data sources at 
finer scales, and any available point scale data through an open data platform. Several current platforms already can play this role, but in the context of water, GEOGLOWS (https: / / www.geoglows.org/ accessed on 20 February 2022) might be the best vehicle to capture such a global effort.

A final major challenge is to quantify uncertainties with all the different water balance components. In this study, the uncertainties in the dam volume estimates related to the remote sensing pixel sizes were quantified [27], but for most of the other approaches the uncertainty remains unclear. This is, of course, not a simple challenge: accurately accounting for all uncertainties (including the observation uncertainties) is no simple task and at this point only approximate uncertainties can be estimated. However, any recognition of associated uncertainties will deliver better decision making and will drive future research.

\section{Conclusions}

Recent developments in remote sensing data and newly developed algorithms mean that observing field scale water balance components has now become feasible. Combining the different parts of the water balance means that assessing whole farm water use efficiency as well as crop water productivity are now within reach. However, some significant challenges remain in relation to quantifying runoff and crop yield and the availability of validation data at the correct scales to verify remote sensing observations. There is a need to collaborate at a global scale to combine existing data and deliver products that are scalable from the point scale to the enterprise level for different levels of input data accuracy and have quantified uncertainties.

Author Contributions: Conceptualization, R.W.V. and I.F.; methodology, R.W.V., I.F., J.B., J.D., P.C.-L. and F.S.; formal analysis, R.W.V., I.F., J.B., P.C.-L. and F.S.; writing-original draft preparation, R.W.V., I.F., J.B., J.D., P.C.-L. and F.S.; writing-review and editing, R.W.V., I.F., J.B. and P.C.-L. All authors have read and agreed to the published version of the manuscript.

Funding: This project has received funding from the European Union's Horizon 2020 Research and Innovation Programme (H2020-SPACE-2018-2020) under grant agreement No. 870344.

Institutional Review Board Statement: Not applicable.

Informed Consent Statement: Not applicable.

Data Availability Statement: Not applicable.

Conflicts of Interest: The authors declare no conflict of interest.

\section{References}

1. Oki, T.; Kanae, S. Global Hydrological Cycles and World Water Resources. Science 2006, 313, 1068-1072. [CrossRef] [PubMed]

2. D'Odorico, P.; Davis, K.F.; Rosa, L.; Carr, J.A.; Chiarelli, D.; Dell'Angelo, J.; Gephart, J.; MacDonald, G.K.; Seekell, D.A.; Suweis, S.; et al. The Global Food-Energy-Water Nexus. Rev. Geophys. 2018, 56, 456-531. [CrossRef]

3. Mekonnen, M.M.; Hoekstra, A.Y. Sustainability of the blue water footprint of crops. Adv. Water Resour. 2020, 143, 103679. [CrossRef]

4. Rattalino Edreira, J.I.; Guilpart, N.; Sadras, V.; Cassman, K.G.; van Ittersum, M.K.; Schils, R.L.M.; Grassini, P. Water productivity of rainfed maize and wheat: A local to global perspective. Agric. For. Meteorol. 2018, 259, 364-373. [CrossRef]

5. Rosa, L.; Rulli, M.C.; Davis, K.F.; Chiarelli, D.D.; Passera, C.; D'Odorico, P. Closing the yield gap while ensuring water sustainability. Environ. Res. Lett. 2018, 13, 104002. [CrossRef]

6. Davis, K.F.; Rulli, M.C.; Garrassino, F.; Chiarelli, D.; Seveso, A.; D’Odorico, P. Water limits to closing yield gaps. Adv. Water Resour. 2017, 99, 67-75. [CrossRef]

7. Quinteiro, P.; Ridoutt, B.G.; Arroja, L.; Dias, A.C. Identification of methodological challenges remaining in the assessment of a water scarcity footprint: A review. Int. J. Life Cycle Assess. 2018, 23, 164-180. [CrossRef]

8. Hoekstra, A.Y.; Hung, P.Q. Virtual Water Trade: A Quantification of Virtual Water Flows between Nations in Relation to International Crop Trade; UNESCO-IHE: Delft, The Netherlands, 2002.

9. Escriva-Bou, A.; McCann, H.; Hanak, E.; Lund, J.; Gray, B.; Blanco, E.; Jezdimirovic, J.; Magnuson-Skeels, B.; Tweet, A. Water Accounting in Western US, Australia, and Spain: Comparative Analysis. J. Water Resour. Plan. Manag. 2020, 146, 04020004. [CrossRef] 
10. Chen, Y.; Colloff, M.J.; Lukasiewicz, A.; Pittock, J. A trickle, not a flood: Environmental watering in the Murray-Darling Basin, Australia. Mar. Freshw. Res. 2020, 72, 601-619. [CrossRef]

11. Bretreger, D.; Yeo, I.-Y.; Quijano, J.; Awad, J.; Hancock, G.; Willgoose, G. Monitoring irrigation water use over paddock scales using climate data and landsat observations. Agric. Water Manag. 2019, 221, 175-191. [CrossRef]

12. Massari, C.; Modanesi, S.; Dari, J.; Gruber, A.; de Lannoy, G.J.M.; Girotto, M.; Quintana-Seguí, P.; Le Page, M.; Jarlan, L.; Zribi, M.; et al. A Review of Irrigation Information Retrievals from Space and Their Utility for Users. Remote Sens. 2021, 13, 4112. [CrossRef]

13. Dixon, H.; Sandström, S.; Cudennec, C.; Lins, H.F.; Abrate, T.; Bérod, D.; Chernov, I.; Ravalitera, N.; Sighomnou, D.; Teichert, F. Intergovernmental Cooperation for Hydrometry-What, Why and How? Hydrol. Sci. J. 2020, pp. 1-15. Available online: https: / / www.tandfonline.com/action/showCitFormats?doi=10.1080\%2F02626667.2020.1764569\&area=0000000000000001 (accessed on 20 February 2022).

14. Blatchford, M.L.; Mannaerts, C.M.; Njuki, S.M.; Nouri, H.; Zeng, Y.; Pelgrum, H.; Wonink, S.; Karimi, P. Evaluation of WaPOR V2 evapotranspiration products across Africa. Hydrol. Process. 2020, 34, 3200-3221. [CrossRef]

15. Mekonnen, M.M.; Hoekstra, A.Y. A global and high-resolution assessment of the green, blue and grey water footprint of wheat. Hydrol. Earth Syst. Sci. 2010, 14, 1259-1276. [CrossRef]

16. Xu, Z.; Chen, X.; Wu, S.R.; Gong, M.; Du, Y.; Wang, J.; Li, Y.; Liu, J. Spatial-temporal assessment of water footprint, water scarcity and crop water productivity in a major crop production region. J. Clean. Prod. 2019, 224, 375-383. [CrossRef]

17. Kayatz, B.; Baroni, G.; Hillier, J.; Lüdtke, S.; Heathcote, R.; Malin, D.; van Tonder, C.; Kuster, B.; Freese, D.; Hüttl, R.; et al. Cool Farm Tool Water: A global on-line tool to assess water use in crop production. J. Clean. Prod. 2019, 207, 1163-1179. [CrossRef] [PubMed]

18. Vanuytrecht, E.; Raes, D.; Steduto, P.; Hsiao, T.C.; Fereres, E.; Heng, L.K.; Garcia Vila, M.; Mejias Moreno, P. AquaCrop: FAO's crop water productivity and yield response model. Environ. Model. Softw. 2014, 62, 351-360. [CrossRef]

19. Bretreger, D.; Yeo, I.-Y.; Hancock, G.; Willgoose, G. Monitoring irrigation using landsat observations and climate data over regional scales in the Murray-Darling Basin. J. Hydrol. 2020, 590, 125356. [CrossRef]

20. Calera, A.; Campos, I.; Osann, A.; D’Urso, G.; Menenti, M. Remote Sensing for Crop Water Management: From ET Modelling to Services for the End Users. Sensors 2017, 17, 1104. [CrossRef]

21. Foster, T.; Mieno, T.; Brozović, N. Satellite-Based Monitoring of Irrigation Water Use: Assessing Measurement Errors and Their Implications for Agricultural Water Management Policy. Water Resour. Res. 2020, 56, e2020WR028378. [CrossRef]

22. Safi, A.R.; Karimi, P.; Mul, M.; Chukalla, A.; de Fraiture, C. Translating open-source remote sensing data to crop water productivity improvement actions. Agric. Water Manag. 2022, 261, 107373. [CrossRef]

23. Guzinski, R.; Nieto, H. Evaluating the feasibility of using Sentinel-2 and Sentinel-3 satellites for high-resolution evapotranspiration estimations. Remote Sens. Environ. 2019, 221, 157-172. [CrossRef]

24. Maselli, F.; Battista, P.; Chiesi, M.; Rapi, B.; Angeli, L.; Fibbi, L.; Magno, R.; Gozzini, B. Use of Sentinel-2 MSI data to monitor crop irrigation in Mediterranean areas. Int. J. Appl. Earth Obs. Geoinf. 2020, 93, 102216. [CrossRef]

25. Fuentes, I.; van Ogtrop, F.; Vervoort, R.W. Long-term surface water trends and relationship with open water evaporation losses in the Namoi catchment, Australia. J. Hydrol. 2020, 584, 124714. [CrossRef]

26. Fuentes, I.; Padarian, J.; van Ogtrop, F.; Vervoort, R.W. Comparison of Surface Water Volume Estimation Methodologies that Couple Surface Reflectance Data and Digital Terrain Models. Water 2019, 11, 780. [CrossRef]

27. Fuentes, I.; Scalzo, R.; Vervoort, R.W. Volume and uncertainty estimates of on-farm reservoirs using surface reflectance and LiDAR data. Environ. Model. Softw. 2021, 143, 105095. [CrossRef]

28. Sandi, S.G.; Saco, P.M.; Saintilan, N.; Wen, L.; Riccardi, G.; Kuczera, G.; Willgoose, G.; Rodríguez, J.F. Detecting inundation thresholds for dryland wetland vulnerability. Adv. Water Resour. 2019, 128, 168-182. [CrossRef]

29. Lettenmaier, D.P.; Alsdorf, D.; Dozier, J.; Huffman, G.J.; Pan, M.; Wood, E.F. Inroads of remote sensing into hydrologic science during the WRR era. Water Resour. Res. 2015, 51, 7309-7342. [CrossRef]

30. McCabe, M.F.; Rodell, M.; Alsdorf, D.E.; Miralles, D.G.; Uijlenhoet, R.; Wagner, W.; Lucieer, A.; Houborg, R.; Verhoest, N.E.C.; Franz, T.E.; et al. The future of Earth observation in hydrology. Hydrol. Earth Syst. Sci. 2017, 21, 3879-3914. [CrossRef]

31. Karthikeyan, L.; Chawla, I.; Mishra, A.K. A review of remote sensing applications in agriculture for food security: Crop growth and yield, irrigation, and crop losses. J. Hydrol. 2020, 586, 124905. [CrossRef]

32. Sheffield, J.; Wood, E.F.; Pan, M.; Beck, H.; Coccia, G.; Serrat-Capdevila, A.; Verbist, K. Satellite Remote Sensing for Water Resources Management: Potential for Supporting Sustainable Development in Data-Poor Regions. Water Resour. Res. 2018, 54, 9724-9758. [CrossRef]

33. Weiss, M.; Jacob, F.; Duveiller, G. Remote sensing for agricultural applications: A meta-review. Remote Sens. Environ. 2020, 236, 111402. [CrossRef]

34. Karimi, P.; Bastiaanssen, W.G.M. Spatial evapotranspiration, rainfall and land use data in water accounting Part 1: Review of the accuracy of the remote sensing data. Hydrol. Earth Syst. Sci. 2015, 19, 507-532. [CrossRef]

35. Ambrosone, M.; Matese, A.; Di Gennaro, S.F.; Gioli, B.; Tudoroiu, M.; Genesio, L.; Miglietta, F.; Baronti, S.; Maienza, A.; Ungaro, F.; et al. Retrieving soil moisture in rainfed and irrigated fields using Sentinel-2 observations and a modified OPTRAM approach. Int. J. Appl. Earth Obs. Geoinf. 2020, 89, 102113. [CrossRef]

36. Gorelick, N.; Hancher, M.; Dixon, M.; Ilyushchenko, S.; Thau, D.; Moore, R. Google Earth Engine: Planetary-scale geospatial analysis for everyone. Remote Sens. Environ. 2017, 202, 18-27. [CrossRef] 
37. Bastiaanssen, W.G.M.; Cheema, M.J.M.; Immerzeel, W.W.; Miltenburg, I.J.; Pelgrum, H. Surface energy balance and actual evapotranspiration of the transboundary Indus Basin estimated from satellite measurements and the ETLook model. Water Resour. Res. 2012, 48, W11512. [CrossRef]

38. Koech, R.; Langat, P. Improving Irrigation Water Use Efficiency: A Review of Advances, Challenges and Opportunities in the Australian Context. Water 2018, 10, 1771. [CrossRef]

39. Feng, B.; Zhuo, L.; Xie, D.; Mao, Y.; Gao, J.; Xie, P.; Wu, P. A quantitative review of water footprint accounting and simulation for crop production based on publications during 2002-2018. Ecol. Indic. 2021, 120, 106962. [CrossRef]

40. Glenn, E.P.; Doody, T.M.; Guerschman, J.P.; Huete, A.R.; King, E.A.; McVicar, T.R.; van Dijk, A.I.J.M.; van Niel, T.G.; Yebra, M.; Zhang, Y. Actual evapotranspiration estimation by ground and remote sensing methods: The Australian experience. Hydrol. Process. 2011, 25, 4103-4116. [CrossRef]

41. Ray, R.L.; Fares, A.; He, Y.; Temimi, M. Evaluation and Inter-Comparison of Satellite Soil Moisture Products Using In Situ Observations over Texas, U.S. Water 2017, 9, 372. [CrossRef]

42. Crow, W.T.; Berg, A.A.; Cosh, M.H.; Loew, A.; Mohanty, B.P.; Panciera, R.; de Rosnay, P.; Ryu, D.; Walker, J.P. Upscaling sparse ground-based soil moisture observations for the validation of coarse-resolution satellite soil moisture products. Rev. Geophys. 2012, 50, RG2002. [CrossRef]

43. Wang, H.; Guan, H.; Gutiérrez-Jurado, H.A.; Simmons, C.T. Examination of water budget using satellite products over Australia J. Hydrol. 2014, 511, 546-554. [CrossRef]

44. Rodell, M.; Velicogna, I.; Famiglietti, J.S. Satellite-based estimates of groundwater depletion in India. Nature 2009, 460, 999-1002. [CrossRef] [PubMed]

45. Nagler, P.L.; Doody, T.M.; Glenn, E.P.; Jarchow, C.J.; Barreto-Muñoz, A.; Didan, K. Wide-area estimates of evapotranspiration by red gum (Eucalyptus camaldulensis) and associated vegetation in the Murray-Darling River Basin, Australia. Hydrol. Process. 2016, 30, 1376-1387. [CrossRef]

46. Drusch, M.; Del Bello, U.; Carlier, S.; Colin, O.; Fernandez, V.; Gascon, F.; Hoersch, B.; Isola, C.; Laberinti, P.; Martimort, P.; et al. Sentinel-2: ESA's Optical High-Resolution Mission for GMES Operational Services. Remote Sens. Environ. 2012, 120, 25-36. [CrossRef]

47. Sanchez, A.H.; Picoli, M.C.A.; Camara, G.; Andrade, P.R.; Chaves, M.E.D.; Lechler, S.; Soares, A.R.; Marujo, R.F.B.; Simões, R.E.O.; Ferreira, K.R.; et al. Comparison of Cloud Cover Detection Algorithms on Sentinel-2 Images of the Amazon Tropical Forest. Remote Sens. 2020, 12, 1284. [CrossRef]

48. Huffman, G.J.; Stocker, E.F.; Bolvin, D.T.; Nelkin, E.J.; Jackson, T. GPM IMERG Final Precipitation L3 1 Month 0.1 Degree x 0.1 degree V06. Available online: https:/ / doi.org/10.5067/GPM/IMERG/3B-MONTH/06 (accessed on 21 April 2021).

49. Hoffmann, L.; Günther, G.; Li, D.; Stein, O.; Wu, X.; Griessbach, S.; Heng, Y.; Konopka, P.; Müller, R.; Vogel, B.; et al. From ERA-Interim to ERA5: The considerable impact of ECMWF's next-generation reanalysis on Lagrangian transport simulations. Atmos. Chem. Phys. 2019, 19, 3097-3124. [CrossRef]

50. McNally, A.; Arsenault, K.; Kumar, S.; Shukla, S.; Peterson, P.; Wang, S.; Funk, C.; Peters-Lidard, C.D.; Verdin, J.P. A land data assimilation system for sub-Saharan Africa food and water security applications. Sci. Data 2017, 4, 170012. [CrossRef]

51. Guerschman, J.P.; van Dijk, A.I.J.M.; Mattersdorf, G.; Beringer, J.; Hutley, L.B.; Leuning, R.; Pipunic, R.C.; Sherman, B.S. Scaling of potential evapotranspiration with MODIS data reproduces flux observations and catchment water balance observations across Australia. J. Hydrol. 2009, 369, 107-119. [CrossRef]

52. Allen, R.G.; Pereira, L.S.; Raes, D.; Smith, M. Crop Evapotranspiration-Guidelines for Computing Crop Water Requirements-FAO Irrigation and Drainage Paper 56. Fao Rome 1998, 300, D05109. Available online: https://www.fao.org/3/x0490e/x0490e00.htm (accessed on 20 February 2022).

53. Rienecker, M.M.; Suarez, M.; Todling, R.; Bacmeister, J.; Takacs, L.; Liu, H.; Gu, W.; Sienkiewicz, M.; Koster, R.; Gelaro, R. The GEOS-5 Data Assimilation System: Documentation of Versions 5.0. 1, 5.1. 0, and 5.2. 0.; NASA Goddard Space Flight Center: Greenbelt, MA, USA, 2008.

54. Japan Meteorological Agency Himawari-8/9 Himawari Standard Data User's Guide (version 1.3). Available online: http: / / www.data.jma.go.jp/mscweb/en/himawari89/space_segment/hsd_sample/HS_D_users_guide_en_v12.pdf (accessed on 31 December 2021).

55. Fisher, A.; Flood, N.; Danaher, T. Comparing Landsat water index methods for automated water classification in eastern Australia. Remote Sens. Environ. 2016, 175, 167-182. [CrossRef]

56. Neves, R. The MOHID concept. In Ocean Modelling for Coastal Management-Case Studies with MOHID; Mateus, M., Neves, R., Eds.; IST Press: Lisbon, Portugal, 2013.

57. Trancoso, A.R.; Braunschweig, F.; Chambel Leitão, P.; Obermann, M.; Neves, R. An advanced modelling tool for simulating complex river systems. Sci. Total Environ. 2009, 407, 3004-3016. [CrossRef] [PubMed]

58. Chambel-Leitão, P.; Ramos, T.; Domingos, T.; Neves, R. Mohid Land-Porous Media, a Tool for Modeling Soil Hydrology at Plot Scale and Watershed Scale. Open Hydrol. J. 2015, 9, 1-12. [CrossRef]

59. Simionesei, L.; Ramos, T.B.; Brito, D.; Jauch, E.; Leitão, P.C.; Almeida, C.; Neves, R. Numerical Simulation of Soil Water Dynamics under Stationary Sprinkler Irrigation with Mohid-Land. Irrig. Drain. 2016, 65, 98-111. [CrossRef] 
60. Galvao, P.; Chambel Leitao, P.; Neves, R.; Leitao, P.C. A different approach to the modified Picard method for water flow in variably saturated media. In Developments in Water Science; Miller, C.T., Farthing, M.W., Gray, W.G., Pinder, G.F., Eds.; Elsevier: Amsterdam, The Netherlands, 2004; Volume 55, pp. 557-567.

61. Jury, W.; Gardner, W.; Gardner, W. Soil Physics; Wiley \& Sons: New York, NY, USA, 1991.

62. Mohanty, B.P.; Cosh, M.H.; Lakshmi, V.; Montzka, C. Soil Moisture Remote Sensing: State-of-the-Science. Vadose Zone J. 2017, 16, 1-9. [CrossRef]

63. Al-Shammari, D.; Fuentes, I.; Whelan, B.M.; Filippi, P.; Bishop, T.F.A. Mapping of Cotton Fields Within-Season Using PhenologyBased Metrics Derived from a Time Series of Landsat Imagery. Remote Sens. 2020, 12, 3038. [CrossRef]

64. Filippi, P.; Jones, E.J.; Wimalathunge, N.S.; Somarathna, P.D.S.N.; Pozza, L.E.; Ugbaje, S.U.; Jephcott, T.G.; Paterson, S.E.; Whelan, B.M.; Bishop, T.F.A. An approach to forecast grain crop yield using multi-layered, multi-farm data sets and machine learning. Precis. Agric. 2019, 20, 1015-1029. [CrossRef]

65. Filippi, P.; Whelan, B.M.; Vervoort, R.W.; Bishop, T.F.A. Identifying crop yield gaps with site- and season-specific data-driven models of yield potential. Precis. Agric. 2021, 1-24. [CrossRef]

66. Roth, G.; Harris, G.; Gillies, M.; Montgomery, J.; Wigginton, D. Water-use efficiency and productivity trends in Australian irrigated cotton: A review. Crop Pasture Sci. 2013, 64, 1033-1048. [CrossRef] 